This PDF is a selection from a published volume from the National Bureau of Economic Research

Volume Title: The Changing Frontier: Rethinking Science and Innovation Policy

Volume Author/Editor: Adam B. Jaffe and Benjamin F. Jones, editors

Volume Publisher: University of Chicago Press

Volume ISBNs: 0-226-28672-X, 978-0-226-28672-3

Volume URL: http://www.nber.org/books/jaff13-1

Conference Date: August 2-3, 2013

Publication Date: July 2015

Chapter Title: Algorithms and the Changing Frontier

Chapter Author(s): Hezekiah Agwara, Philip Auerswald, Brian Higginbotham

Chapter URL: http://www.nber.org/chapters/c13030

Chapter pages in book: (p. $371-410)$ 


\title{
Algorithms and the Changing Frontier
}

\author{
Hezekiah Agwara, Philip Auerswald, and \\ Brian Higginbotham
}

\begin{abstract}
Everywhere, economic activity is turning outward by embracing shared business and technology standards that let businesses plug into truly global systems of production.

—Sam Palmisano, former CEO of IBM $(2006,130)$
\end{abstract}

\subsection{Introduction}

"What is the frontier?" Frederick Jackson Turner asked in his seminal work, The Frontier in American History (1893). "In the census reports it is treated as the margin of that settlement which has a density of two or more to the square mile"(3). When Turner wrote of the closing of the American frontier, he was referring to the end of an interval that lasted over three hundred years, as the first European settlements in the North American continent grew and expanded westward. The frontier was viewed as a place, bounded on one side by the easternmost fields cleared for agriculture and on the other by the westernmost wilderness. In between, Turner argued, was a marginal space in which necessity was, even more than elsewhere, the mother of invention.

By the time Franklin Delano Roosevelt wrote to Vannevar Bush in November 1944 to request the report celebrated in this research volume, the frontier itself had changed. "New frontiers of the mind are before us," Roosevelt wrote, "and if they are pioneered with the same vision, boldness,

Hezekiah Agwara is affiliated faculty at the School of Policy, Government, and International Affairs of George Mason University. Philip Auerswald is associate professor at the School of Policy, Government, and International Affairs of George Mason University. Brian Higginbotham is a PhD candidate at the School of Policy, Government, and International Affairs of George Mason University.

We thank Adam Jaffe, Ben Jones, Tim Simcoe, and participants in the NBER "The Changing Frontier: Rethinking Science and Innovation Policy" preconference and conference for their comments. We also thank Lewis Branscomb, Stuart Kauffman, José Lobo, and Karl Shell for their contribution to developing ideas central to this chapter via jointly authored work, and W. Brian Arthur for helpful conversations, insights, and inspiration. For acknowledgments, sources of research support, and disclosure of the authors' material financial relationships, if any, please see http://www.nber.org/chapters/c13030.ack. 
and drive with which we have waged this war we can create a fuller and more fruitful employment and a fuller and more fruitful life" (Bush 1945b). Much as Thomas Jefferson had charged Meriwether Lewis and William Clark to survey the previously unexplored domains of the West in 1803, so Roosevelt tasked Bush to survey previously unexplored domains of human inquiry. The desired endpoint of the undertaking was the same in both cases: to improve lives and increase prosperity.

The title of the report Bush produced, Science: The Endless Frontier, expressed succinctly how societal progress was defined by the middle of the twentieth century. Released in July 1945, a month after the Allied victory in Europe and a year before George Doriot created the world's first publicly owned venture capital firm, Bush's report was about how best to maintain in peacetime a rate of scientific progress that had been unprecedented when driven by the necessities of war.

The frontier of scientific knowledge has advanced at least as dramatically in the nearly seventy years since 1945 as the frontier of the American West advanced in the seventy years after 1803 . In both cases, the advancement was part of "the changing frontier" that has been a central feature of American economic history, which in turn is the title of this volume. The real change related to the evolution of the frontier itself.

It is significant that America's first World's Fair opened in Philadelphia exactly seventy years after Lewis and Clark returned to St. Louis at the end of their two-year expedition. The International Exhibition of Arts, Manufacturers, and Products of the Soil and Mine, as it was officially called, was a sort of museum in reverse in which inventions that signaled the creation of major new industries were first exhibited to the general public. These included Alexander Graham Bell's telephone (communications technology), the Remington typewriter (office services), the Wallace-Farmer Electric Dynamo (electric power), and Heinz ketchup (food processing). Indeed, there is considerable poetic significance in the fact that Frederick Jackson Turner first presented his renowned paper on "The Significance of the Frontier in American History" before the American Historical Society at a subsequent World's Fair - the 1893 World's Columbian Exposition in Chicago.

What of today? Where is the changing frontier of societal advance situated in 2013, both in the United States and globally? Is that frontier expanding or closing? These are the questions we seek to answer in this chapter.

To be clear, we recognize from the outset the parallel relevance of multiple notions of the "frontier." From the standpoint of a single firm or of a nation, we can think of the frontier as the boundary of economic production given existing technology and techniques - the "production possibilities frontier" (PPF) whose origins trace back to the early nineteenth century and the work of David Ricardo. We can also define the frontier in a global sense in terms 
of the boundaries of scientific advance, much in the way that Vannevar Bush employed the term. Or, as Cesar Hidalgo, Ricardo Hausmann, and coauthors have recently explored, ${ }^{1}$ we can define the economic frontier for any region or country in terms of the country's existing (and constantly evolving) production capabilities.

In this chapter we are arguing that these three concepts of the frontierthe frontier of industry, the frontier of science, and the frontier of what we will call algorithms - actually define an advancing frontier of their own. That advancing "frontier of frontiers" is global.

The way we think about the frontier obviously affects how we seek to measure it. Total factor productivity serves to measure the advance of aggregate production possibilities. Patents can (with well-known limitations) measure the advance of the scientific frontier. Measures of the advance of the algorithmic frontier are less well developed. We propose some potential proxies in this chapter.

We develop our argument in three stages. In section 11.2 we introduce the idea of "the algorithmic frontier" through a summary of the progression of the idea of the frontier in American history. In particular we summarize different dominant interpretations of the frontier over the past four hundred years of US history: agricultural (1610s-1880s), industrial (1890s-1930s), scientific (1940s-1980s), and algorithmic (1990s-present). We then go back and motivate the idea of the algorithmic frontier a second time, from the standpoint of the evolution of economic theory. We argue (as suggested above) that the progression of historical frontiers (or, more precisely, of the frontier of frontiers) finds its direct parallel in the progression of economic theory.

In section 11.3 of the chapter we set the stage for proposing potential measures of the advance of the algorithmic frontier by discussing the relationship of "production recipes" (a term with historical resonance in economics that we use interchangeably with "production algorithms"), standards, and interoperability (both within and between firms). This section of the chapter provides a bridge to sections 11.4 and 11.5, in which we argue that the last thirty years of the centuries-old process referred to as "globalization" has been, more than ever before, defined by the adoption of standards and associated improvement in the interoperability of production algorithms. This is where our argument connects directly with Hidalgo and Hausmann (2009) and Hausmann et al. (2011), as well as with considerable prior literature that emphasizes the algorithmic substructure of the global exchange economy.

Finally, in section 11.6, we tie the chapter back to the core theme of this volume by discussing how the advance of the algorithmic frontier has affected the process of scientific discovery and technological innovation. Section 11.7 concludes. 


\subsection{Changing Frontiers in the United States}

\subsubsection{Historical Context}

The first American frontier requires little description. The map in figure 11.1 illustrates the movement of the frontier westward from 1803 through the nineteenth century. The social complexity of the process of westward movement - a subject of active scholarly inquiry in the century since Turner presented his paper-yields to remarkable simplicity when looked at from a cartographic perspective. Inexorably, the frontier moved westward until European settlements covered a continent. The economy of the United States during this lengthy interval was defined by two industries: agriculture and the extraction of natural resources. Accordingly, we refer to this first, most famous frontier in American history as the agricultural frontier.

The second American frontier was not the scientific one that formed the subject of the Bush report, but its industrial precursor. The World's Fair was to the era of the industrial frontier what the earliest precursors of the rodeo were to the era of the agricultural frontier: places where successful experimentation could be recognized and rewarded. The inventive wave that had been building since the 1870 s continued to gain force. In the first decade of the 1900s alone the Wright brothers flew the first plane at Kitty Hawk, Henry Ford sold his first Model A, Samuel Insull merged Commonwealth Electric with Chicago Edison to create Commonwealth Edison - the world's first large-scale electric utility - and major breakthroughs were made in the development of the radio.

The frontier for the United States in the first third of its history was thus about realizing economies of scale afforded by the combination of new technologies and new modes of social organization. The era from the 1890s to the 1930s (in particular from roughly 1910 to the start of World War II) was the one in which the basic infrastructure of the modern United States was developed. The high-level industrial classifications that experienced the greatest growth during this interval include utilities, electric equipment and supplies, rubber and plastic products, petroleum and coal products, and printing and publishing. ${ }^{2}$ The inventions listed above were among the sparks that ignited the industrial engine of the early twentieth century.

Bibliometric analysis provides a particularly vivid lens through which to view the changing industrial frontier. Figure 11.2 presents data on word frequencies created using Google Ngram, which is based on a digital database of more than 5.2 million books published worldwide between 1500 and 2008 comprising more than 500 billion words. Around that database Google created an interface they call the Ngram Viewer, which enables users to plot the frequency with which words and phrases appear in this data set over time. ${ }^{3}$ The Ngram tool can

2. Data from the Historical Statistics of the United States and the Census of Manufacturers. 3. See http://books.google.com/ngrams. 


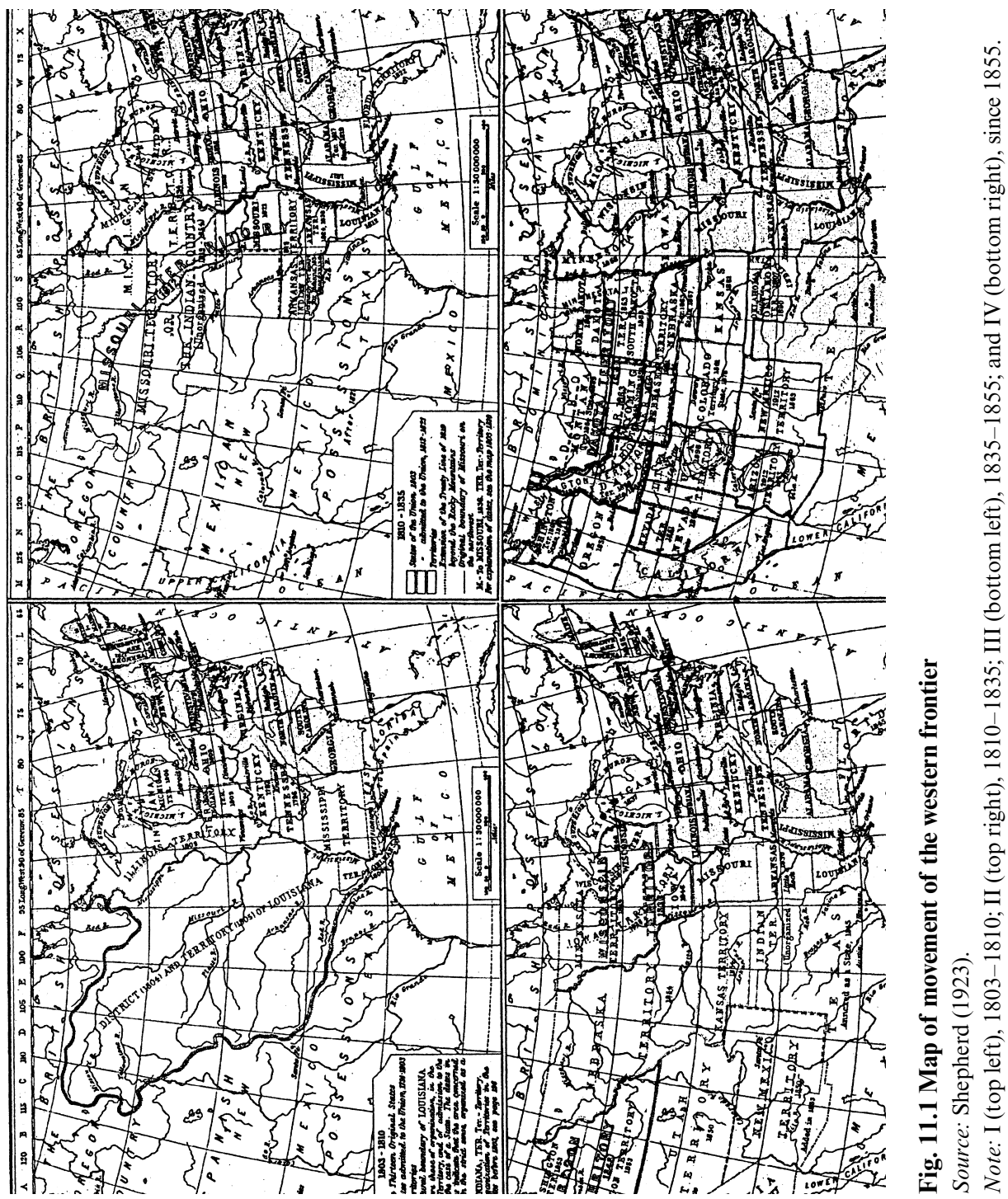




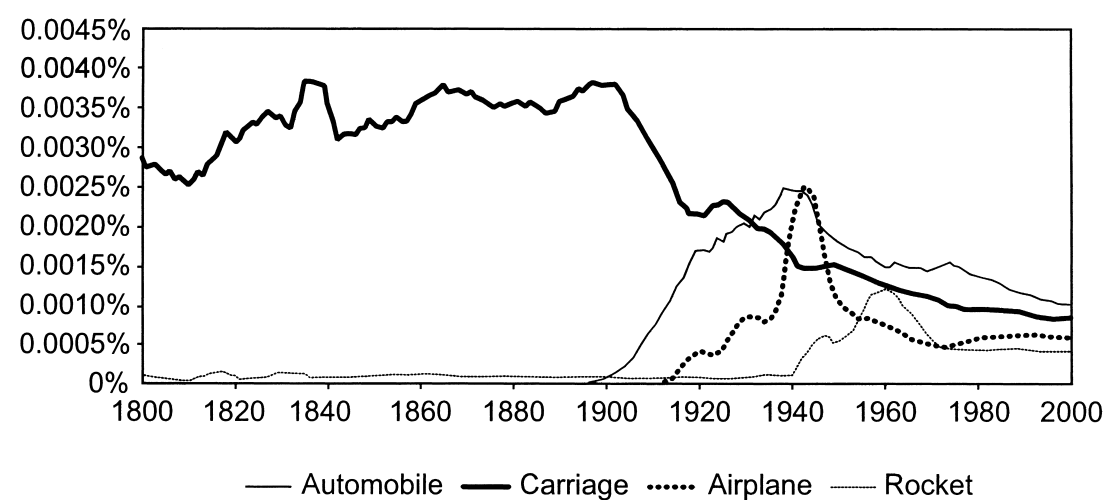

Fig. 11.2 Ngram, "carriage, automobile, airplane, and rocket"

be used to get a sense of the intensity of interest in particular technologies over time - put simply, the relative frequency with which particular words appear in published works of any type, for every year since 1500. Figure 11.2 presents a sample plot using the words "carriage, automobile, airplane, and rocket." The pattern shown for each of these words is consistent with the "hype cycle" hypothesized by Gartner Consulting, illustrated in figure 11.3. In the Gartner model, societal interest (which we conjecture is correlated with word frequencies in the Ngram database) in a technology grows rapidly after its first introduction. Interest soon reaches a peak, after which an era of disillusionment sets in. Interest falls off, usually just as the foundation for widespread societal adoption is setting in. By the time a technology is ubiquitous, its everyday usage is roughly constant; economic stability is reflected by this bibliometric stability. ${ }^{4}$

Although the plot in figure 11.2 is a simple representation of word frequency over time, it has some interesting characteristics. First, from 1900 to 1940, use of the word "carriage" decreases at just about the same rate that use of the word "automobile" increases; this is consistent with our intuition about the introduction of a more powerful substitute technology. Second, consistent with the Gartner hypothesis, the peak of relative intensity of usage comes well before technological maturity and market ubiquity. Finally, for these two words at least, the "hype cycle" seems to become increasingly compressed over time. This is consistent with considerable data that documents the increasing rates of adoption of new technologies and shorter product life cycles over time.

The inventions that defined the industrial frontier from 1890 through the 1930s represented major advances not just for the United States, but for humanity on a global scale. However, these inventions were the out-

4. For more on the Gartner hype cycle see http://www.gartner.com/technology/research/ methodologies/hype-cycle.jsp. 


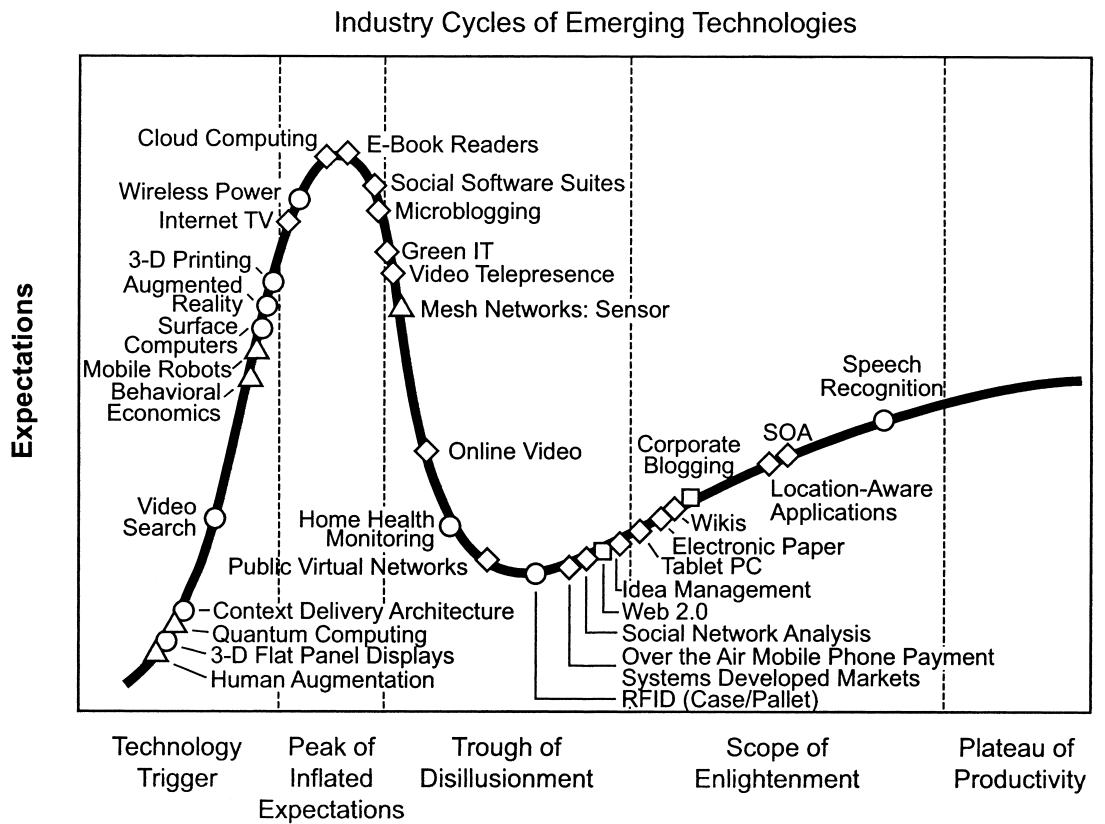

Time

Years to mainstream adoption:

less than 2 years $\diamond 2$ to 5 years $\bigcirc 5$ to 10 years $\Delta$ more than 10 years

Fig. 11.3 Gartner "hype cycle"

Note: For more on hype cycles, see http://www.gartner.com/technology/research/methodologies/ hype-cycle.jsp.

come not of scientific research but of systematic tinkering. In the middle of the twentieth century the nature of invention began to change; invention became more scientific, with scientific research playing an increasing role in motivating major advances. ${ }^{5}$

5. Joseph Schumpeter wrote of the innovation as early as 1928 that within the emerging "trustified" capitalism "innovation is no longer . . embodied typically in new firms, but goes on, within the big units now existing. . . . Progress becomes 'automatised,' increasingly impersonal and decreasingly a matter of leadership and individual initiative." (384-85). By 1958, John Jewkes, David Sawers, and Richard Stillerman wrote:

"In the twentieth century . . the individual inventor is becoming rare; men with the power of originating are largely absorbed into research institutions of one kind or another, where they must have expensive equipment for their work. Useful invention is to an ever-increasing degree issuing from the research laboratories of large firms which alone can afford to operate on an appropriate scale. . . Invention has become more automatic, less the result of intuition or genius and more a matter of deliberate design" (31).

This world of systematic innovation - if not based on science, per se, then on research more generally understood - represents the frontier that Vannevar Bush described, and sought to advance, in Science: The Endless Frontier. 


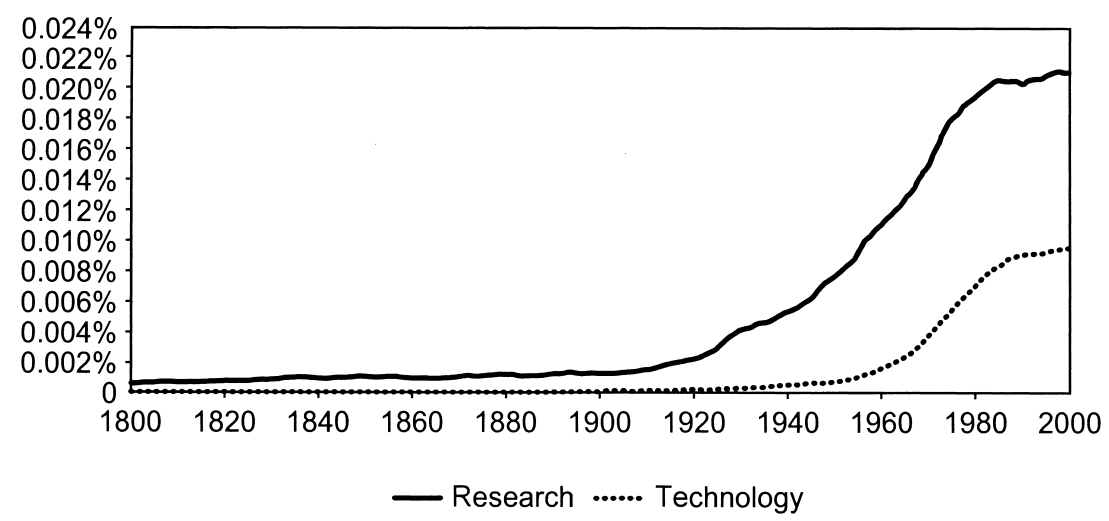

Fig. 11.4 Ngram, "research, technology"

Again, simple word-frequency plots help illustrate. Figure 11.4, also created with Google's Ngram tool, illustrates the intensity of usage of the words "research" and "technology" from 1800 to 2000. Rarely used before 1900, "research" begins to gain currency only in the 1920s, rises steadily, and then levels off starting in the 1980s. Technology follows a similar trend, but the period of rapid rise begins in the 1960s.

Figure 11.5 illustrates the system of science-based innovation that came into being following World War II. Advances in fundamental knowledgethe basic science column on the left-hand side - undergird the system of science-based innovation in a modern economy. Of course, advances in basic science will have no impact on economic growth or human well-being if they do not translate first into technologies, and ultimately into goods and services. The core technologies represented in the second column are the direct translation of science into a capability for innovation. Core technologies may be developed within the university, in an entrepreneurial start-up, or, most commonly, in the existing corporation. Core technologies typically are combined to create new goods and services. Industry production networks organized around existing goods and services are represented in the third column from the left. Industry production networks, or industry "clusters" when localized, are defined in terms of goods and services, not in terms of technologies. On the far right-hand side are the product markets themselves, where consumers and workers are situated. Innovations that renew or recreate existing industries not infrequently originate with workers near a production process, or with consumers of a product or service, rather than in a lab or university.

As Bush foresaw, this system has yielded significant dividends for American society. Tremendous scientific advances were made at Bell Telephone Laboratories, DuPont, General Electric, RCA Laboratories, the IBM T. J. Watson Research Center, the Xerox Palo Alto Research Center, together defining a 


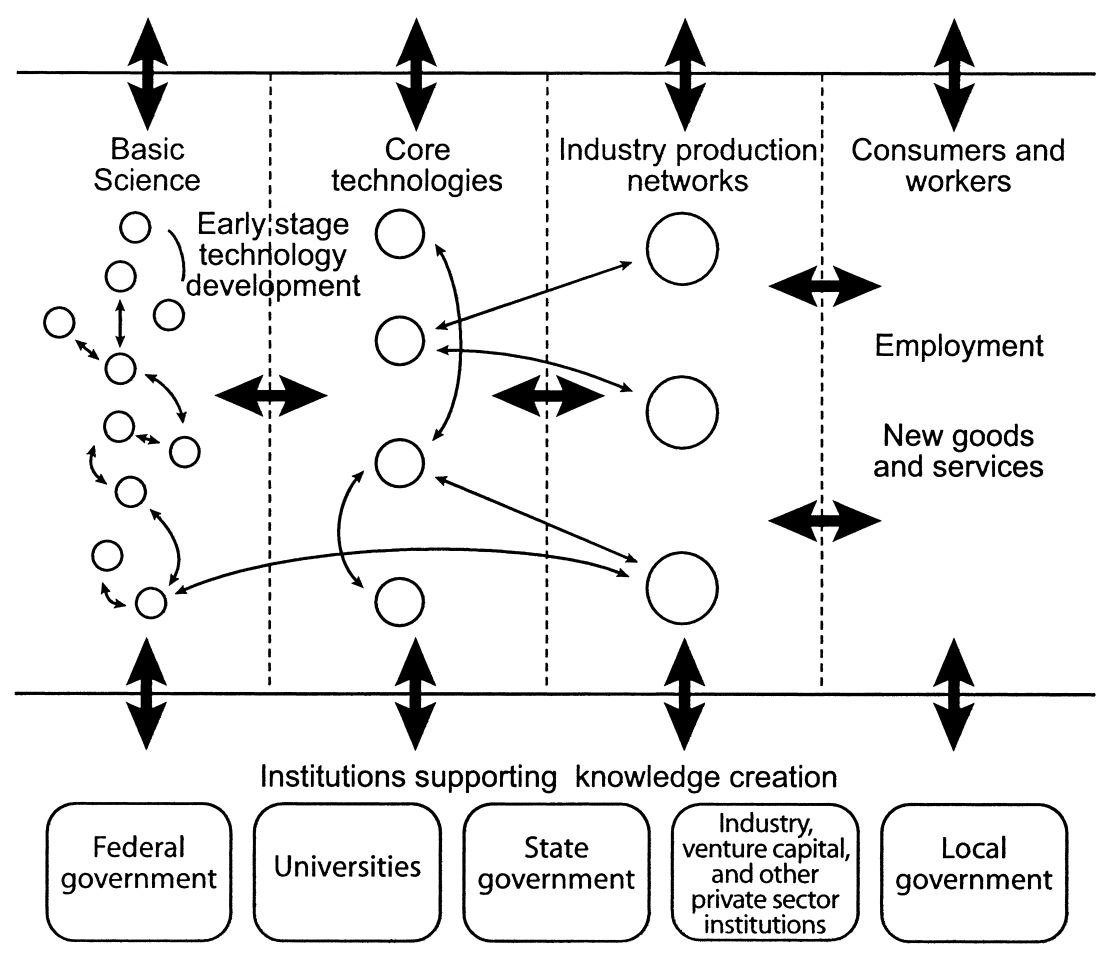

Fig. 11.5 Post-WWII system of science-based innovation

golden age of corporate research and development (R\&D) in the United States (Auerswald and Branscomb 2005). It was the work that took place in these laboratories - arguably at least as much as that in universities, which was more distant from market applications - that defined the scientific frontier that drove the advance of the US economy in the post-World War II era (Trajtenberg, Henderson, and Jaffe 1992).

Coming fifty years after the publication of Turner's classic work on the closing of the western frontier, the title of the Bush report was significantly expansive: Science: The Endless Frontier pointed to a dimension of human attainment that would not be subject to limitation, as the prior era had been. In the case of the westward expansion, an insurmountable obstacle ultimately was reached: the Pacific Ocean. To Bush and those of his generation, no such obstacle was foreseeable when it came to the scientific frontier. An end to science-based innovation was essentially inconceivable. Yet by the 1970s, fewer private firms - regardless of their size - found it to be in their interest to invest in the sort of basic research that the Bush report had championed. One by one, the great corporate laboratories either closed or sharply narrowed their focus. 
Table 11.1

R\&D and GDP, US average annual real GDP growth rates, unadjusted and $R \& D$ adjusted: 1959-2007 (percent)

\begin{tabular}{lccc}
\hline Period & Unadjusted real GDP $^{\mathrm{a}}$ & R\&D-adjusted real GDP $^{\mathrm{b}}$ & Difference $^{-}$ \\
\hline $1959-2007$ & 3.32 & 3.39 & 0.07 \\
$1959-1973$ & 4.20 & 4.33 & 0.13 \\
$1974-1994$ & 3.02 & 3.03 & 0.01 \\
$1995-2001$ & 3.76 & 3.93 & 0.17 \\
$2002-2007$ & 2.75 & 2.87 & 0.12 \\
\hline
\end{tabular}

Source: Lee \& Schmidt (2010) and Bureau of Economic Analysis, National Science Foundation Science and Engineering Indicators, (2013).

${ }^{\text {a }}$ As published in the national income and product accounts (NIPAs).

${ }^{b}$ Real GDP with R\&D treated as investment and the double-counting of R\&D software removed.

Macroeconomic data also suggests that a significant structural shift took place in the economic frontier in the 1970s. Using a methodology developed by the Bureau of Economic Analysis (BEA), Lee and Schmidt (2010) calculate the changes to the gross domestic product (GDP) that result from treating $\mathrm{R} \& \mathrm{D}$ as an investment rather than as an expense (table 11.1). They find that recategorizing $R \& D$ in this manner adds 0.13 percent to GDP growth rates from 1959 to 1973. However, from 1973 to 1994, the impact vanishes. This coincides with the much-discussed productivity slowdown, as well as the "conglomerate" discount experienced by the largest and most diversified US corporations starting in the late 1960s.

In the BEA analysis, the recategorization of $R \& D$ as investment once again begins to change the calculation of GDP growth rates appreciably from 1995 to 2007. As Jorgenson and Stiroh (2000) have documented, the primary vehicle by which $R \& D$ was contributing to GDP growth in the late 1990s and early in the twenty-first century was via innovations in information and communications technology (ICT). The new frontier was, and is, algorithmic rather than research-based.

This is not to say that the system of science-based innovation described in figure 11.5 has vanished. Far from it: it is larger and more robust than ever. As in prior eras, the infrastructure developed during the advance of one frontier remains fundamental to society as the next develops. Agricultural output increased for decades after the agricultural frontier was overtaken by the industrial frontier. Manufacturing output increased for decades after the industrial frontier was overtaken by the scientific frontier. Similarly, the output of science-based innovation has continued to increase even as that frontier has been overtaken by the algorithmic frontier.

\subsubsection{Theoretical Context}

We can readily describe the difference between agricultural, industrial, scientific, and algorithmic frontiers using standard production theory. Each 
of the first three frontiers has an associated domain within economics. The economics of the agricultural frontier were Malthusian, the economics of the industrial frontier were those of neoclassical growth theory, and the economics of science-based innovation are those of the particular variant of growth theory advanced in Romer $(1986,1990)$. In this section, we argue that the algorithmic frontier may require different economics as anticipated long ago by Simon (1967), Winter (1968), and Arrow (1974), and partially articulated more recently by Aghion and Howitt (1992), Kremer (1993), Romer (1996), Weitzman (1998), Hidalgo and Hausmann (2009), Hausmann et al. (2011), Bloom and Van Reenen (2010), and Arthur (2009, 2011), among others.

In a Malthusian world, land is the fundamental fixed factor, whereas populations are variable. Accordingly, rents accrue to land, and an interval of growth (though ephemeral) can be realized only through geographical expansion. Long-term growth is infeasible.

In an industrial model, capital replaces land. Investment can increase the capital-to-labor ratio. This increases the marginal product of labor, and thus the wage rate. Both the rate of population growth and the rate of technical change are exogenous. Growth is a matter of reaching the steady state level of per-capita consumption, which in turn is limited by the rate of technological advance. This, writ large, is the familiar world of the neoclassical growth model.

In the science-based model, technical change is the result of active investment. Knowledge is nonrival and nonexcludable, so the outcomes of R\&D investments spill over to the economy as a whole. ${ }^{6}$ Achieving economic equilibrium in the presence of aggregate increasing returns to knowledge is feasible so long as the research technology exhibits locally decreasing returns. Long-term growth rates can be increased by subsidizing research or the accumulation of human capital. This, writ large, is the familiar growth model set forth in Romer $(1986,1990)$.

How does the algorithmic model differ from the science-based model? Where the science-based model (like the Bush report) is built on the assumption that the transmission of economic knowledge is (or at least can be) costless and error free, the algorithmic model takes the costly process by which ideas are created, stored, shared, combined, and, of course, connected to economic exchange as the central problem of economic life.

The algorithmic model recognizes the possibility of a global best practice, or optimum, but does not assume that all firms, or all countries, will operate

6. This notion is associated with the work of Romer $(1986,1990)$, though it is present many other places. "Nonrival" means that one person's use of an idea does not keep another person from using the idea, "nonexcludable" means that it is impossible to keep a person from using an idea once it is "out in the open," and "knowledge spillovers" refers to the costless transmission of ideas that are nonrival and nonexcludable. Romer (1996) also employs the term "recipes" to refer to production algorithms, following both Simon (1967) and Winter (1968). 
at this point. Even within the United States not all firms within an industry operate at the production possibilities frontier. While some firms maintain an advantaged position through nonmarket competition, there is a deeper trend at work in this new frontier.

The algorithmic model recognizes that research and development is an important element inside the black box of productivity, but that research and new knowledge creation are necessary but insufficient conditions to allow firms to operate at the boundary of the production possibilities frontier. This reflects the fact that there is diversity in the productivity levels of knowledge creation, which forms the basis of comparative advantage. This diversity in knowledge - itself the outcome of path-dependent processesleads to diverse levels of productivity in product innovation. ${ }^{7}$

New knowledge creation through research and development plays a crucial role in economic growth, but the diversity in productivity levels within or between countries is also a function of the diversity of productivity levels in process innovation. The algorithmic model internalizes the insight that management quality varies and that management heterogeneity is central to understanding observed differentials between regions and nations. ${ }^{8}$ When firm-level managers oversee the evolution of a production algorithm, they may emphasize different components of a management strategy. As an example, Bloom and Van Reenen (2010) find that American firms are better at providing incentives but are worse at monitoring than are managers in Sweden. Process innovation has always mattered but because of increasing organizational complexity from dispersed production networks, production algorithms and the organization of information are now defining the frontier of economic progress as never before.

In this light, consider the notion, central to the science-based model, that ideas are both "nonrival" and "nonexcludable," and economically relevant innovations are characteristically subject to "knowledge spillovers." In the algorithmic model, the ideas that actually propel growth and development are overwhelmingly uncodified, context dependent, and transferable only at significant cost - which is to say that tacit knowledge dominates, information asymmetries are the norm, and transactions costs are significant. ${ }^{9}$

While knowledge spillovers of the type that are central to the science-based model clearly exist, they are unlikely to be of significant relevance in the practical work of creating the new business entities that drive twenty-first-century

7. Hidalgo and Haussman (2009), and Hidalgo et al. (2011).

8. Goldfarb and Yang (2009).

9. Important early work by Mansfield $(1961,1963)$ on the subject of technological change related to imitation by one firm of the production methods of another. This work advanced the studies by Griliches (1957) on technological adoption. Where Griliches had used published data to study the adoption of essentially modular agricultural technologies, Mansfield (1961) used questionnaires and interviews to study the adoption of new production techniques by large firms in four industries. 
global value chains. ${ }^{10}$ The reason for this is that most productive knowledge is firm specific and producers far from dominant production clusters must learn to produce through a process of trial and error. Market-driven innovation involves the search for ideas that are rivalrous and excludable (at least temporarily), out of which ventures with proprietary value can be created. The impediments to innovation that matter most are not a lack of appropriability of returns but the everyday battles involved in communicating ideas, building trust, and making deals across geographically disparate regions and diverse economic units. ${ }^{11}$ To the extent that the public benefits not captured by the investing firm (resulting from knowledge spillovers or other mechanisms) are temporally far off or uncertain, it is unlikely that they will be of greater importance to innovation-related decision making than will be the immediate, first-order challenges of organizing and financing the firm's operations. ${ }^{12}$

In the next section we develop this idea further. We first define "production recipes," a term that has historical resonance in economics that we will use interchangeably with "production algorithms." We then consider how the adoption of standards enables the interoperability of firm-scale production recipes. We argue that improvements in interoperability have been essential to the functioning of complex supply chains, and in this manner have been central to the story of unprecedented growth experienced globally in the past decade.

\subsection{Production Recipes, Standards, and Interoperability}

\subsubsection{Production Recipes}

Schumpeter (1912) famously wrote, "Technologically as well as economically considered, production 'creates' nothing in the physical sense. In both cases it can only influence or control things and processes, or 'forces.' . . . [T] produce means to combine the things and forces within our reach. Every method of production signifies some definite combination. . . The carrying out of new combinations we call 'enterprise'; the individuals whose function it is to carry them out we call "entrepreneurs" (14). The "new combinations" that entrepreneurs create are combinations of interdependent activities that jointly constitute the organization. These are "routines" in the language of Nelson and Winter (1982), "organizational capabilities" in the language of Chandler $(1990,1992)$, and "production recipes" in the language of Winter (1968) and Auerswald et al. (2000).

10. We emphasize that the focus here is not on web pages and pirated music videos. These digitized products - even including patents - are not the same thing as production algorithms or recipes.

11. Auerswald (2008).

12. Bloom and Van Reenen (2010). 
In this chapter, we employ "production recipes" as our term of choice to describe combinations of interdependent activities that jointly constitute an organization. In this language, we can readily think of mangers as "cooks" who oversee the execution of existing, well-known recipes while entrepreneurs are more like "chefs," improvising new recipes-which is to say, creating new combinations. ${ }^{13}$

The use of the term "recipe" serves as a reminder that the sort of routinized processes of production we seek to describe with this term are as old as human society itself. Among the oldest Sumerian tablets are ones that describe actual recipes (e.g., for the production of beer) as well as numerical algorithms. ${ }^{14}$ Indeed, we will employ the term "recipe" interchangeably with "production algorithm."

The idea of a recipe was clearly expressed by Winter $(1968,9)$ : “Knowing how to 'bake a cake' is clearly not the same thing as 'knowing how to bring together all of the ingredients for a cake.' Knowing how to bake a cake is knowing how to execute the sequence of operations that are specified, more or less closely, in a cake recipe." In the algorithmic model, this distinction takes on first-order importance: knowing how to bake a cake is different from knowing how to bring together all of the ingredients for a cake.

Figure 11.6, drawn from Auerswald et al. (2000), illustrates this point. ${ }^{15}$ A neoclassical production plan is a particular input-output relationship. In its simplest rendition, it is a point $(x, y)$ where $x \geq 0$ is the quantity of the input and where $y \geq 0$ is the quantity of the output. Figure 11.6 shows the production possibilities of the firm, the shaded area $T$, and three specific possible production plans labeled A, B, and C. The production function in this figure exhibits constant returns to scale, such that the best a firm can do is

$$
y=\theta x,
$$

where $\theta$ is a positive scalar that can be thought of as the organizational capital of the most productively efficient firm. The production function is comprised of the set of input-output pairs that lie on the boundary of the production possibilities set.

All of this is just a restatement of standard theory. Now, however, assume further that the approach utilized by the firm to convert inputs to outputs is encoded as a program. This program runs inside the "black box" of the standard production function to convert inputs to outputs.

For the sake of illustration, let us say that a given production process is comprised of three operations, each of which can be conducted in one

13. We thank Irwin Feller for sharing this analogy. See also Auerswald (2012).

14. Knuth (1972) and Auerswald (2012).

15. The description of figure 11.6 that follows in the next three pages is drawn from Auerswald (2010) and Auerswald and Branscomb (2005). 


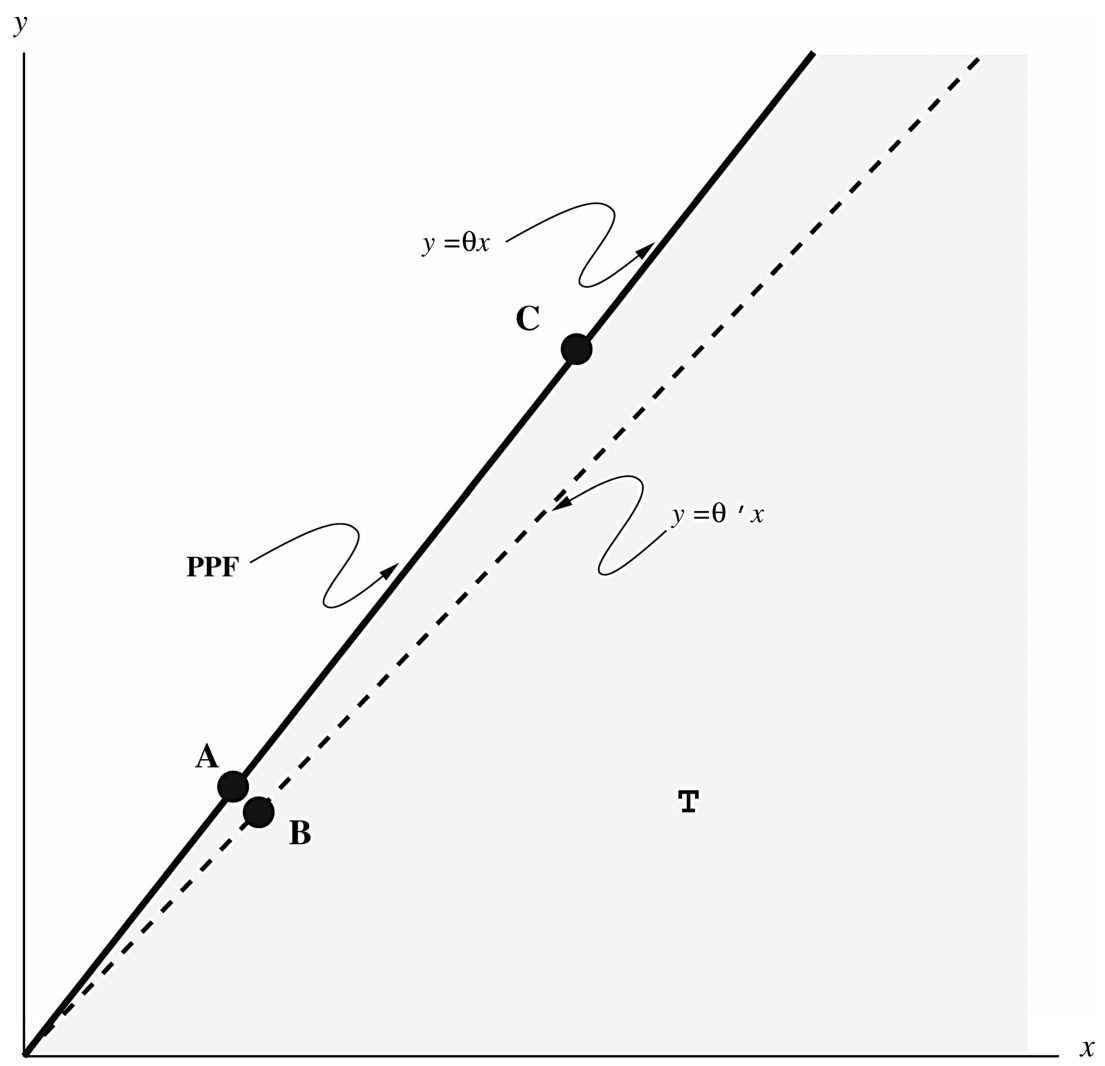

Fig. 11.6 Production possibilities frontier

Source: Auerswald et al. (2000).

of just two ways. We can exhaustively enumerate all possible production recipes as the set of eight binary strings $\{000,001,010,100,011,101,110$, $111\}$. Each of these recipes will be associated with its own scalar measure of effectiveness. Let us refer to the level of effectiveness as the "organizational capital" associated with the recipe. For example, recipe 010 might be associated with organizational capital $\theta$, and recipe 101 might be associated with organizational capital $\theta^{\prime}$. Let us arbitrarily say that recipe 010 is the best of the bunch, so its associated level of organizational capital is greater than the organizational capital associated with any of the other recipes.

Referring back to figure 11.6, input-output pair A, which lies on the boundary line as defined by $y=\theta x$, clearly "dominates" input-output pair $\mathrm{B}$; the firm using recipe 010 produces more output with less input than the firm using recipe 101 . For all firms to operate on the production possibilities frontier requires (a) that all firms have knowledge of the elements of the set 
of potentially usable recipes, and (b) that all firms are aware of the effectiveness of each recipe in actual production. Under such conditions, all firms in this example would use production recipe 010 .

Figure 11.6 also allows us to clearly see the difference between economic distance and technological distance. From an economic standpoint, input-output pair A is close to input-output pair B but distant from inputoutput pair C. However, from the standpoint of technology, pairs A and C are the same, as they are produced with the same recipe (010); input-output pair $B$ is maximally different from both $A$ and $C$, in that the recipe used to produce $\mathrm{B}$ differs in every operation from that used to produce pairs $\mathrm{A}$ and C. Taking one operation at a time, $0 \neq 1 ; 1 \neq 0 ; 0 \neq 1$. Since there are three operations in all and the two recipes differ in every operation, the technological distance between the two recipes is 3 .

The complexity of a production recipe can be represented either in terms of both the number of "operations" or distinct units involved in the production process or (critically) the extent of the interdependence between those units. ${ }^{16}$ The greater the complexity of technology as defined in terms of interdependence, the lower the correlation between the effectiveness of the original production recipes (i.e., the leader's method) and that of the same recipe altered slightly (i.e., an imperfect imitation). ${ }^{17}$

In the Romer $(1986,1990)$ science-based model, technological distance does not exist; newly discovered recipes add to aggregate knowledge as soon as they are put into practice. In the algorithmic model, the search for better recipes is constrained both by technological distance and by the complexity of the production process. Newly discovered recipes that are not easily imitated are the essence of economic differentiation and the basis for above-normal profits.

\subsubsection{The Historical Importance of Standards}

According to the International Organization for Standards (ISO 2004, 4), standards are a "document, established by consensus and approved by a recognized body, that provides, for common and repeated use, rules, guidelines or characteristics for activities or their results, aimed at the achievement of the optimum degree of order in a given context." The term "optimum order" is significant. The standardization of interfaces allows for a system-wide optimization of the balance between order and flexibility in the supply

16. Coase (1937) argued that, in the presence of technological interdependencies, firms will expand to realize economies of scope. When firms do expand in such a manner to internalize the externalities, they create what Auerswald et al. (2000) term "intrafirm externalities." Indeed, if one particular unit of a firm is not linked to any other via such intrafirm externalities, then we reasonably wonder why that unit is part of the firm to begin with (rather than, for example, acting as an outside contractor). In this sense, a transactions cost theory of the firm predicts that, in industries where technological interdependencies abound, managers will typically be charged with solving complex coordination problems.

17. See Auerswald (2010) and related prior work, and also Rivkin (2000). 
chain. ${ }^{18}$ Standards are one form of codified knowledge that have been critical in sharing technical knowledge and expanding the reach of the market. ${ }^{19}$

The first emperor of China, Qin Shi Huangdi (221 to 206 BC), standardized both writing and weights and measures, with the aim of increasing trade within the newly unified country. From the invention of bills of exchange in the Middle Ages, to the development of universal time in the late nineteenth century and container shipping in the mid-twentieth century, innovations in standards have lowered the cost and enhanced the value of exchanges across distances. In the process, they have created new capabilities and opportunities on a global scale.

In our most recent period of globalization, the role of standards grew in importance as trade resumed in the post-World War II era. High transactions costs initially impeded trade, despite the emphasis on open markets and the resumption of (mostly) free trade through the Bretton Woods institutions. Some of the impediments stemmed from difficulties at the transition points of the global economy rather than tariff levels per se. One of the dominant forces driving the algorithmic frontier has been an unceasing quest to harmonize standards globally.

Thus, the growth of supply chains and the role of standardization in facilitating efficient chains have been critical to the functioning of global markets. Standardization of containerized shipping ${ }^{20}$ and pallets, ${ }^{21}$ two seemingly innocuous and generally unheralded developments, combined to transform global trading patterns. Entrepreneurs Malcolm McLean in shipping and Norman Cahners in pallets, performing an essential operations research task, were responsible for these two transformations. ${ }^{22}$ As a result of these standards, global shipping costs fell from over $\$ 5.86$ per ton in the 1950 s to about $\$ 0.16$ today. ${ }^{23}$

The European adoption of the global system for mobile communications (GSM) standards is another example of the benefit of standards harmonization. While Europe achieved rapid advances in mobile technology, in the United States the Federal Communications Commission (FCC) decided not to adopt an official cellular standard but to allow competition to select the optimal technology. ${ }^{24}$ As a result, the market became segmented in the United States, with different companies each lobbying for their proprietary

18. Auerswald (2012).

19. It is evident, of course, that standards can also restrict trade. For a thorough discussion see, for example, World Trade Organization, 2005 World Trade Report: Exploring the Links between Trade, Standards and the WTO.

20. Levinson (2008).

21. Vanderbilt (2012), Raballand and Aldaz-Carroll (2007).

22. Levinson (2008), Vanderbilt (2012).

23. Murphy and Yates $(2009,50)$. One result of the decline in transportation costs has been the rise of just-in-time manufacturing practices that have been the drivers of modern growth for firms like Honda, Toyota, and Walmart (Levinson 2008).

24. Guasch et al. (2007). 
standards. Adoption of cellular technology was slower in the United States as a result..$^{25}$

More generally, the diffusion of mobile phones based on the two dominant standards (GSM and code division multiple access [CDMA]) is one of the most astounding cases of the expansion of the algorithmic frontier. In 2000 there were fewer than 740 million mobile phone subscriptions, or roughly 16 per 100 inhabitants; ${ }^{26}$ by 2012 there were more than 6.3 billion subscriptions (101 per 100 inhabitants). The rapid diffusion was facilitated by the adoption of technical standards that enable communications to occur over a common network. Once the technology was standardized, it was comparatively easy for firms like Vodafone to move into untested markets.

Instead of building extensive landline networks, developing countries built mobile towers and "leap-frogged" the older technology. The fastest growing mobile markets between 2002 and 2008 were in Africa, India, and China. ${ }^{27}$ This is even true when we look at conflict-ridden environments such as Afghanistan and Pakistan. ${ }^{28}$ In Afghanistan, the number of subscriptions rose from under 30,000 in 2000 to more than 18 million in 2012. The case of Pakistan is even more remarkable: in 2000 the number of mobile subscriptions was 360,000 , and rose to more than 120 million by 2012 .

The standards underlying GSM and CDMA encompass one layer in what engineers refer to as the internet protocol stack. The five layers of the TCP/IP protocol stack are: applications, transport, Internet, link (or routing), and physical. ${ }^{29}$ The modular design of the protocol stack allows engineers to design standards for one stack independent of the others. Thus, at the application level, for instance, the World Wide Web Consortium (W3C) can focus on web design and applications standards like HyperText Markup Language (HTML) and Cascading Style Sheets (CSS). This allows for an efficient division of labor in standard creation and allows firms within standard-setting organizations to develop expertise at a given layer. ${ }^{30}$

In many areas of government regulation, but particularly in environmental regulation where standards are binding, firms operating in multiple jurisdictions may face different regulations. In order to comply, firms will often choose to adhere to the most stringent, an effect colloquially referred

25. Over time this has been important, but because mobile standards are updated almost every ten years, the lock-in effect from settling on a potentially inferior standard is reduced; the United States appears to have become slightly more innovative recently (Dodd 2012).

26. Data from ITU (2013). Retrieved from http://www.itu.int/en/ITU-D/Statistics/Documents/ statistics/2013/Mobile_cellular_2000-2012.xls.

27. Kalba (2008), Sauter and Watson $(2008,20)$.

28. Auerswald (2012).

29. The Internet Engineering Task Force (IETF) defines the standard in RFC 1122, Host Requirements, and defines four layers. Authors frequently refer to the Link and Physical layers separately, although in RFC 1122 they are considered one layer.

30. Simcoe (forthcoming). 
to as "so goes California." The phenomenon applies to many areas beyond environmental standards and regulations.

For the past thirty years, as global ties have deepened, firms have found that dealing with the financial and accounting rules in different jurisdictions can be a regulatory hurdle that advantages large firms with extensive financial and accounting departments. Two global efforts have gradually pushed the international financial system toward a harmonized set of standards.

In the United States, FASB (Financial Accounting Standards Board), at the direction of the US Securities and Exchange Commission (SEC), has led the transition from US generally accepted accounting principles (GAAP) accounting standards to the International Financial Reporting Standards (IFRS). The IFRS began as a system to harmonize financial accounting standards within the European Union, but as with California's environmental regulations, the value of global harmonization was quickly appreciated. Progress has been slow, but the efforts are ongoing, and the United States is gradually transitioning to the globally recognized standards.

In addition to accounting standards, the Bank for International Settlements has coordinated efforts to harmonize capital standards in the banking industry. There are currently three sets of accords, Basel I, Basel II, and Basel III. The United States and other industrialized countries are in the implementation phase of Basel III, while developing countries are typically at earlier stages. Most low-income countries are making progress at implementing Basel II, especially when large global financial institutions are present. ${ }^{31}$

Of comparable significance to these global standards have been withinfirm standards that define and hold together global supply chains. From the sourcing of raw materials to the marketing of final goods, procurement contracts between buyers and suppliers depend on clear communication of expectations and specifications, all facilitated by standards.

\subsubsection{Types of Standards}

Our theoretical understanding of standards is limited and the categories that are most commonly identified are somewhat arbitrary because standards can blur formal boundaries. Kindleberger (1983) provided one early attempt at understanding the economic role of standards. He identified two primary purposes: "to reduce transactions costs and to achieve economies of scale through product interchangeability" (395). David (1987) observed that standards could perform both functions and that it might be preferable to classify standards based on the economic problem they solve (e.g., compatibility standards). One common characteristic intrinsic to all standards is that they codify technological knowledge. ${ }^{32}$ 
Standards are classified based on their function and also on whether they are formal or informal. Informal or de facto standards are norms or requirements that may be voluntarily adopted and that frequently arise as a result of path dependence. Formal, or de jure, standards have the force of law behind them, either as laws, regulations, or contracts. ${ }^{33}$ These are flexible categories and there may be some movement between types over time.

Whether standards have the force of law or simply gain network effects and de facto status, they are typically classified in one of four categories: reference, compatibility, interchangeability, and quality standards, with some room for overlap ${ }^{34}$ (Blind 2004; David and Greenstein 1990; Guasch et al. 2007).

Reference standards (information or measurement standards) tie the value of one object to a reference base (NIST/SEMATECH 2012.) A weight measurement serves as a metaphor or simile. For example, a standardized pound in a scale is used to measure a comparable weight of another object, such as a bag of oranges (Busch 2011). Standardized weights and measures are a typical example of these standards (NIST/SEMATECH 2012.) Reference standards can also serve as coordination mechanisms. Landes (1983) describes the historical importance of establishing the measurement of time. Today dates and time have been codified by ISO 8601 - data elements and interchange formats.

Compatibility (interface) standards enable different components of a system to work together because they are based on common characteristics. The extensive network of railroads is a clear example because commercial and passenger rail both work on the same tracks. ${ }^{35}$

Compatibility standards are among the most ubiquitous. According to Farrell and Simcoe (2013), compatibility standards account for more than 40 percent of the total stock of American National Standards. Because the infrastructure encompassing ICT is inherently modular, compatibility standards dominate in this field. Biddle, White, and Woods (2010) estimate that a modern laptop utilizes at least 251 , and perhaps more than 500 , unique compatibility standards.

The next two standards, interchangeability and quality, can be thought of as subsets of compatibility standards. Interchangeability (variety reducing) standards refer to parts that are interchangeable and for the most part identi-

33. Rycroft and Kash (1999).

34. There are other classification systems. For example, ISO/IEC (2014) defines three categories. "Standards can be broadly subdivided into three categories, namely product, process and management system standards. The first refers to characteristics related to quality and safety for example. Process standards refer to the conditions under which products and services are to be produced, packaged or refined. Management system standards assist organizations to manage their operations. They are often used to help create a framework that then allows the organization to consistently achieve the requirements that are set out in product and process standards."

35. Blind (2004), David and Greenstein (1990), and Guasch et al. (2007). 


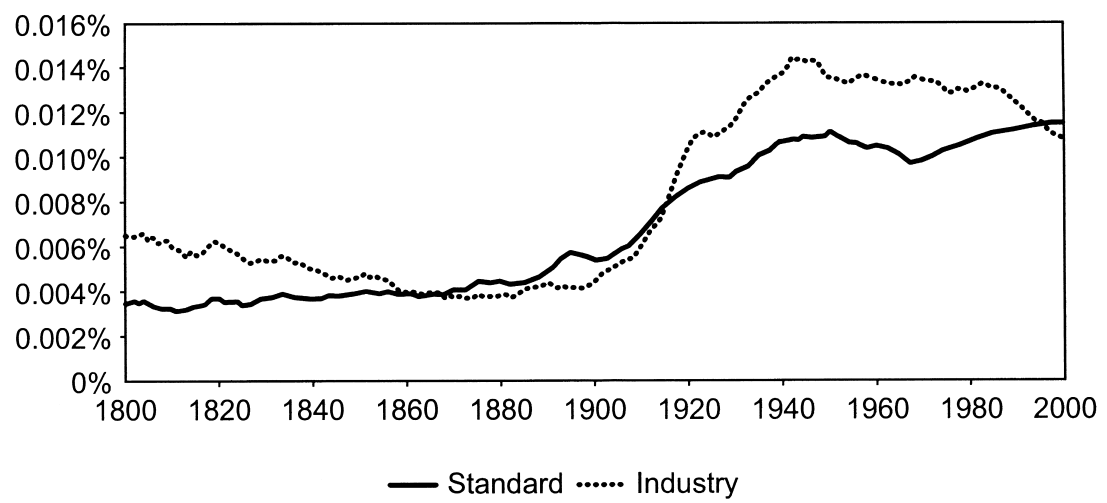

Fig. 11.7 Ngram, "industry, standard"

cal. The industrial revolution and the rise of assembly line processes at the beginning of the twentieth century required that tools in engineering be standardized. ${ }^{36}$ As a result, standardized components from one manufacturer can be expected to work just as well as another. This is not limited to engineering but extends to many practical products, such as paper products. ${ }^{37}$

Quality (and safety) standards certify to consumers that a product or service was produced in a specific manner with a consistent minimum allowable quality. The best known standards are the ISO quality management standards, which are discussed in section 11.5. Health and safety standards for toys, food, drugs, and electrical appliances fall into this category as well. ${ }^{38}$

\subsubsection{The Creation and Maintenance of Standards}

The creation and maintenance of standards is a social activity at least as much as it is technical. While basic research, invention, and technological innovation can create ever-expanding menus of technological options, the process of standardization involves inducing a potentially large set of stakeholders to agree on a single choice. Solving such coordination problems is difficult and costly. Furthermore, those most knowledgeable about the relative strengths and weaknesses of various standards options are also often those with the most at stake in deciding which standards are selected.

The role of standards grew in importance following the American Civil War and the rise of science-based industry during the Second Industrial Revolution. The first standards institutions arose during this time. Figure 11.7, also created with Google Ngram, shows the concomitant rise in the

36. Brady (1961).

37. Guasch et al. (2007) and Blind (2004).

38. Guasch et al. (2007). 
use of the words "industry" and "standard." 39 The gradual development of standards institutions followed three stages in which: (a) standards were localized within the firm or other administrative unit, (b) standards were agreed at the national level by one industry, and (c) standardization was carried out at an international scale.

In practice, because of the benefits of sponsoring a standard, international standard-setting is an almost unavoidably contentious and difficult process. It usually occurs in one (or a combination) of four ways. ${ }^{40}$

First, standards may arise through the decentralized choice of market participants. Second, firms may find it easier to negotiate, typically through a formal standard setting organization (SSO) or independent industry consortia. Third, a dominant market leader may set a standard, which smaller firms may follow. Finally, a standard may be set ex post through converters or multihoming. ${ }^{41}$

It is important to note that the convergence of international standards and global supply chain footprints has offered opportunities to both small and large players. Within these opportunities lie leverage points for systemic change. Increased efficiencies in the operation of global supply chains have enabled Walmart to grow over the past fifty years to become the world's largest private employer. ${ }^{42}$ Yet the same shared global infrastructure famously has allowed the flat-screen TV manufacturer Vizio to develop the best logistics partnerships in its industry - from manufacturers in China to distribution through Costco - despite employing a minimal core staff. ${ }^{43}$

\subsubsection{Standards and Interoperability}

Global enterprise requires interoperability. This interoperability is being developed in a cumulative manner, piece by piece, and new standards are required at every stage. ${ }^{44}$

Standards have become increasingly important in the era of the algorithmic frontier because they enable the interoperability of firm-level recipes. The existence of standards turns a firm-level recipe into a subroutine of a larger program comprising many different recipes. That larger program enumerates the full instructions for the operation of a supply chain. As Paul Agnew, an early proponent of international standards, pointed out, compatibility standards resolve the difficulties that arise "at the transition points - points at which the product passes from department to department

39. One important trend to notice is that standards have continued to grow in importance even though industry trails off starting in the 1980s.

40. This section draws on Farrell and Simcoe (2013).

41. Converters allow different platforms to work together. Mutlihoming refers to the process of making a product, such as a video game, available on two different platforms, like the Sony PlayStation or Microsoft Xbox.

42. If Walmart was a country it would be China's eighth-biggest trading partner, ahead of all but the largest economies. See http://www.edf.org/page.cfm?tagID=2101.

43. See http://hbswk.hbs.edu/pdf/item/6424.pdf. The apparel manufacturer Li \& Fung is among companies that have pursued a similar strategy (Hagel and Brown 2005).

44. Baldwin and Clark (2000). 
within a company, or is sold by one company to another or to an individual" (Agnew, quoted in Murphy and Yates [2009], 7). Without standards, the interdependencies between the firm-level recipes comprising a supply chain would grow at a greater rate than the length of the chain, and the operation of the supply chain would be unmanageable.

Note that standardization to enable the interoperability of recipes as subroutines is different from the standardization of firm-level recipes themselves. In the food service industry, standardized recipes and production processes have famously been the success of franchise-based firms like McDonald's and KFC. Such firms have contributed to advancing the algorithmic frontier, but the particularly strict form of encoding that the franchise model represents is not the focus of this chapter.

Along similar lines, we can argue that the domain of analysis relating to general purpose technologies (GPTs) is really about the nesting of production recipes. Following from Schumpeter's observation that "[t]o produce means to combine the things and forces within our reach," we can readily observe that technologies themselves are frequently combined into other technologies, as subcomponents. Such technologies-acting-as-subcomponents themselves encode production recipes. ${ }^{45}$ The recombination of technologies is thus, implicitly, the recombination of subroutines within a recipe. The GPTs are technologies that operate at lower-more fundamental-levels of such an algorithmic hierarchy (aka supply chain). ${ }^{46}$

In the next section we continue this line of argument by proposing that the recent phenomenon referred to as "globalization" is actually better understood as the progression of the algorithmic frontier, enabled by standards that in turn facilitate interoperability - both among and within supply chains.

\subsection{Globalization Is Really Standardization}

The recent wave of global integration termed "globalization" tends to be described in terms of the international integration of commodity, capital, and labor markets (Bordo, Taylor, and Williamson 2003). If this is what we mean by the term, however, then it is clear that our current period is not

45. The automated teller machine (ATM) or the rice cooker are two examples of physical technologies (hardware) encoding specific subroutines of a production recipe-in the first case, as executed by a teller sitting at a window in a physical bank, and in the second case as executed by a cook in a kitchen. In the case of ATMs, the process has iterated forward again in the past three to four years as significant elements of the functioning of the ATMs (software/hardware) have been encoded as "apps" on mobile phones, making them subroutines of the functioning of another technology (the phone).

46. With regard to general purpose technologies, the seminal reference is Bresnahan and Trajtenberg (1995). Doyne Farmer and James McNerney have sought recently to formalize the idea that a supply chain constitutes an instance of a production ecology, and further that the hierarchies of nested subroutines that, in the aggregate, comprise the production algorithm for the supply chain are equivalent to "trophic levels" in such an ecology. The lower the trophic level of a given technology (which is to say, of the subroutine the technology encodes) the more "general purpose" the technology. 
the first example of globalization. There have been two major periods of globalization (Baldwin and Martin 1999) since the mid-nineteenth century. The first began in the mid-nineteenth century and ended with the onset of World War I. After an interlude between the wars that included the Great Depression, the second era of globalization began during the reconstruction after World War II. Growth in trade accelerated following the end of World War II, but in the past century we have seen trade flows of comparable magnitude to our current experience. ${ }^{47}$ This type of global integration has actually been occurring for at least one thousand years, although the flow of information has not always been from the West to the East (Sen 2002). ${ }^{48}$

What makes the current era unique and different from prior eras of globalization? Alternatively, what has been the driver of the shift from the scientific frontier to the algorithmic? The primary difference between the algorithmic frontier and the earlier era of the scientific frontier is the rise of distributed networks of production and innovation (Auerswald and Branscomb 2008). In this view, globalization is really a process of interdependence and interconnectedness (Acs and Preston 1997). The real driver expanding the algorithmic frontier is the increasing reach of collaborative networks of all kinds-particularly production, but also research. ${ }^{49} \mathrm{As}$ Branstetter, $\mathrm{Li}$, and Veloso write in this volume (chapter 5), "The important role of multinational corporations in the international invention explosions in China and India may help to explain why they are occurring at an early stage of economic development." The production networks themselves are the direct result of standardization. For that reason, we argue that globalization is really standardization.

Shared standards and business practices have been a precondition to this process of economic integration. In contrast with the traditional multinational assembly of subsidiaries, the global enterprise is a flexible assembly of firms around the world, with skills and capacity that can be drawn upon for the most efficient combination of business processes. The rapid globalization and economic integration witnessed in recent years has, in this manner, created the need for standardization of management systems, which are essentially the interface layer between production subroutines. As then-CEO of IBM Palmisano wrote in 2006:

[S]tarting in the early 1970s, the revolution in information technology (IT) improved the quality and cut the cost of global communications and business operations by several orders of magnitude. Most important, it

47. Foreign direct investment as a share of GDP, starting with the third wave of democracy in 1974, accelerated from 5.2 percent between 1950 and 1973 to 25.3 percent from 1974 to 2007 (WTO 2008).

48. Sen (2002) cites as examples the transfer of knowledge of mathematics (decimal system) from India to the West, and of paper, gunpowder, and the printing press from China to Western Europe, among other technologies.

49. The resulting diversity of production levels is thus a result of the degree of incumbency and competition in an industry (Auerswald 2012). 
standardized technologies and business operations all over the world, interlinking and facilitating work both within and among companies. This combination of shared technologies and shared business standards, all built on top of a global IT and communications infrastructure, changed the sorts of globalization that companies found possible. ${ }^{50}$

With diverse productivity levels among firms, companies in "ascending markets" within the developing world have faced significant signaling challenges in the global marketplace. In addition, they must manage information and compliance costs and adopt a common language of exchange. The result has been a remarkable increase in certain standards, or norms, issued by international organizations. We discuss this trend in the next section.

\subsection{Using Quality Management Standards to Map the Movement of the Algorithmic Frontier}

Despite the importance of standards, empirical research on standardization has made only limited progress since the late $1990 \mathrm{~s} .{ }^{51}$ The adoption of technical standards has proved difficult to measure. Data limitations and the potential for endogeneity have plagued the empirical study of the effects of adopting standards. ${ }^{52}$

Standards are well known to be associated with both costs and benefits from a social welfare standpoint. On the side of social costs, standards may serve as impediments to technical advancement or function as a nontariff barriers to trade.$^{53}$ On the social benefit side, the literature suggests at least three potential categories of positive impact. First, the existence of internationally recognized process standards may lower barriers of entry into production and distribution networks on a global scale, thereby enabling trade and making it more inclusive. Second, achieving functional compatibility and interoperability according to global norms may facilitate the adoption of platform technolo-

50. Palmisano $(2006,130)$. The transformation of IBM, which embodied the large-scale research-based firm of the scientific era, epitomizes the structural evolution that has taken place on a global scale. Once the epitome of the industrial giant with an international reach driven by science-based innovation - at its peak in the 1960s-1970s, IBM was investing half of its net income on developing new products and spent more money on computing research than the federal government (Acs 2013, 72) - IBM is today best "understood as global rather than multinational" (Palmisano 2006, 127). The change involves sourcing production from a variety of firms in different countries, and marketing the resulting products globally as well. Palmisano describes the integration of China and India into the global economy as the "most visible signs of this change." Between 2002 and 2003, he writes, foreign firms built sixty thousand manufacturing plants in China, many of them targeting global markets. Similar ties with firms in India are expanding the base from which global products and services are created.

51. Among the few firm-level studies of the decision to seek certification from global standards bodies are Chen, Wilson, and Otsuki (2008) and Guasch et al. (2007).

52. Clougherty and Grajek (2012).

53. World Trade Organization (2005). 
gies. Third, the process of obtaining and maintaining standards certification may serve as an important learning tool and lead to increased productivity through standardized routines; such learning expands the set of capabilities present in the economy, expanding the set of pathways for growth in the manner described by Hidalgo and Hausmann (2009) and Hausmann et al. (2011).

One source of data to help map the movement of the algorithmic frontier on process certifications is the International Organization for Standardization. Formed by the United States along with the other leading powers in 1947-just two years after Vannevar Bush published Science: The Endless Frontier - the International Organization for Standardization (abbreviated as "ISO" for reasons explained in footnote) ${ }^{54}$ was designed to complement the functions of existing national standards bodies ${ }^{55}$ by providing a wider forum for the agreement, adoption, and dissemination of standards.

Today the two most common ISO management standards are the ISO 9000 and 14000 series, which have been supplemented in recent years by standards for information security management, food security, and, most recently, social responsibility (ISO 26000), among others. ${ }^{56}$

The ISO 9000 addresses "quality management," which covers what an organization does to fulfill quality and regulatory requirements, enhance customer satisfaction, and achieve continual performance improvement. ${ }^{57}$ The ISO 9000 consists of internationally accepted principles and requirements for managing an enterprise so as to earn the confidence of customers and markets. ${ }^{58}$ Among the ISO standards the ISO 9000 series of quality management standards are the most general standards, and thus particularly interesting from our standpoint as they most plausibly relate to the management of integration with other subroutines within a global supply chain.

The adoption of ISO 9000 series of standards has occurred on a massive, global scale. The ISO 9000 series quality-management standards are diffused across more than 170 countries, but certification remains concentrated. Table 11.2 presents the top ten countries by certified firms, which account

54. According to the ISO, "because 'International Organization for Standardization' would have different acronyms in different languages ('IOS' in English, 'OIN' in French for Organisation internationale de normalisation), its founders decided to give it an all-purpose shortened name. They chose 'ISO,' derived from the Greek isos, meaning 'equal.' Whatever the country, whatever the language, the short form of the organization's name is always ISO." From http:// www.iso.org/iso/about/discover-iso_isos-name.htm.

55. Notably, the American National Standards Institute in the United States and the British Standards Institute in the United Kingdom.

56. The appendix provides a summary description of the ISO quality-management standards.

57. The immediate predecessor to ISO 9000 was BS 5750, a quality-management standard in Great Britain. Since its inception, ISO 9000 quality-management standards have transitioned beyond manufacturing and have become widespread across industries, including the service sector, as can be seen in table 11.3. Despite the widespread adoption of these standards across industries, the existing literature has been concerned with the trade effects from the adoption of these standards in agriculture (Swann 2009).

58. Furusten (2002). 
Top ten countries for ISO 9001 certificates, 2011

\begin{tabular}{llc}
\hline Rank & \multicolumn{1}{c}{ Country } & Number of certificates \\
\hline 1 & China & 328,213 \\
2 & Italy & 171,947 \\
3 & Japan & 56,912 \\
4 & Spain & 53,057 \\
5 & Germany & 49,450 \\
6 & United Kingdom & 43,564 \\
7 & India & 29,574 \\
8 & France & 29,215 \\
9 & Brazil & 28,325 \\
10 & Korea, Republic of & 27,284 \\
& Sum & $817,631(73.5 \%)$ \\
& All Others & $294,067(26.5 \%)$ \\
& Total & $1,11,698$ \\
\hline
\end{tabular}

Source: ISO survey (2013).

Table 11.3

Top five industrial sectors for ISO 9001 certificates 2011

\begin{tabular}{clc}
\hline \multicolumn{1}{c}{ Sector } & Number of certificates \\
\hline 1 & Services & 203,970 \\
2 & Basic metal and fabricated metal products & 101,848 \\
3 & Construction & 83,864 \\
4 & Electrical and optical equipment & 79,237 \\
5 & Machinery and equipment & 58,427 \\
\hline
\end{tabular}

Source: ISO survey (2013).

for more than two-thirds of the total certifications in 2011. There are two notable trends in these data. First, the new frontier in quality processes, or process design algorithms, has expanded globally through distributed networks of production. The fast-growing BRIC countries (Brazil, Russia, India, and China) constitute more than a third of total certifications, and three countries are in the top ten: Brazil (no. 9), China (no.1), and India (no. 7). Russia (no. 14) and South Africa (no. 39), which are increasingly identified with these emerging markets, also rank quite highly. South Korea, the most rapidly growing country in the world during the past half century, ${ }^{59}$ rounds out the top ten.

The change in the composition of the top ten countries between 1993, the first year for which data is available, and 2011 is striking. In 1993 the top ten countries were, in order, the United Kingdom, Australia, the United States,

59. We omit Equatorial Guinea, which experienced the greatest rate of growth in per capita income of any country in the world in the fifty years after 1960, but without any appreciable advance in economic development measured along other dimensions. 
France, Germany, the Netherlands, South Africa, Ireland, Italy, and Denmark; South Africa was the only nondeveloped country included and one of only a few outside Western Europe. The wide acceptance and adoption of the ISO series has expanded the algorithmic frontier and enhanced the capabilities and opportunities for firms in the developing world.

The distributed nature of production networks is clear from these data. More than one-quarter of firms with foreign ownership (the majority-owned foreign affiliates of parent companies) are ISO certified.$^{60}$ However, the ISO story is not limited to the case of the parent companies of multinationals in developed countries imposing quality standards on their foreign subsidiaries. Interestingly, the top-certified developing countries, or ascending markets, did not dominate firms by country in 2011. Instead, industrialized firms in Japan, Western Europe, and the United States (no. 11) also found benefits from adopting management standards, such as the ISO 9000 series. Firms seeking ISO certification in the developed world include those at the technological frontier, such as General Electric (in energy, health care, and related services) and Netgear (ICT), which proudly proclaim their ISO certifications on their websites. Even in cases where product quality is undisputed, managers find the process of codifying the production process to be a useful activity ${ }^{61}$ This survey evidence may imply that management standards are an important link in global supply chains but that they are not simply a procurement standard.

Figure 11.8 graphs the adoption rates of a broader range of ISO qualitymanagement standards. The data follow a similar pattern, with initial adoption in Western Europe followed by gradual adoption outside the region. This process appears to have accelerated following the successful implementation of the ISO 9000 set of standards.

While the potential benefits of adopting ISO standards have been studied extensively, the literature has produced few clear results. Pathways of benefits vary among studies as well. The ISO adoption is alternately conjectured to function as a signal of competitiveness, to be associated with productivity enhancements and firm learning, or to lead to enhanced compatibility via a common-language effect.

If there is a consensus in the literature on ISO adoption, it is that the benefit of certification to the certified firm is at least as much in the widening of market opportunities as it is in the achievement of process-quality

60. Authors' calculations from World Bank Enterprise Survey (enterprisesurveys.org); majority-owned foreign affiliates are defined as businesses in which an investor of another country holds at least 10 percent voting ownership (BEA 2013).

61. Corbett and Luca (2002).

Terlaak and King (2006), however, argue that there must be other tangible financial incentives to justify the outlay of substantial organizational resources to obtain certification, so that the decoupling of the certification effect and the quality effect is not sustainable in a longer-run equilibrium. 


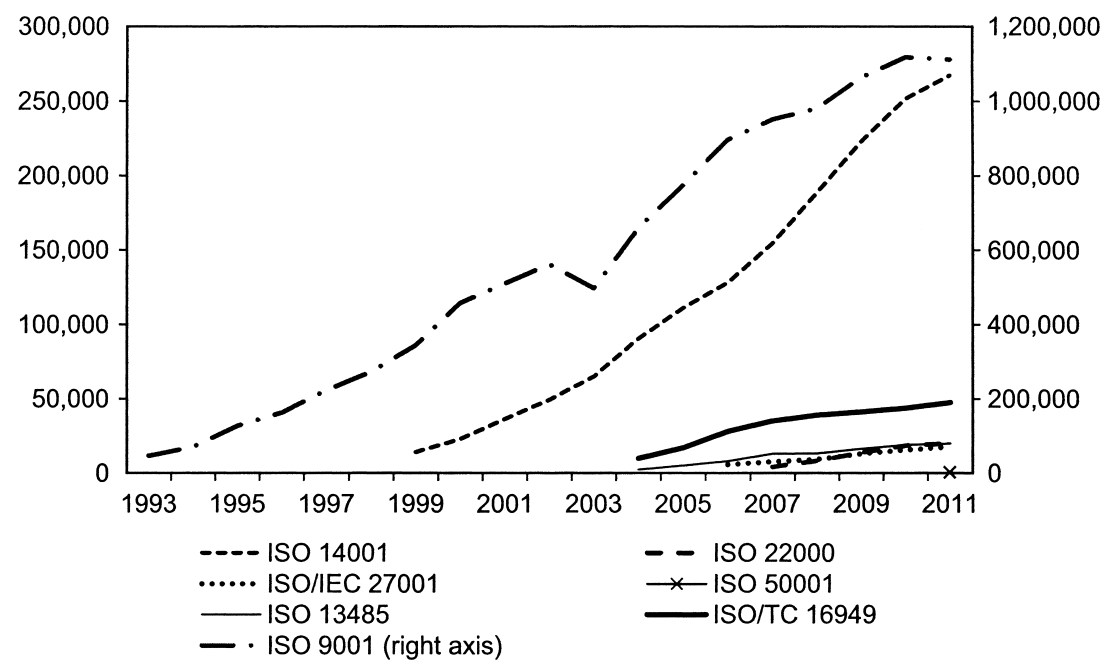

Fig. 11.8 Adoption path of ISO quality management standards

improvements. ${ }^{62}$ A model developed by Terlaak and King (2006) suggests that certification with a management-quality standard may reduce information asymmetries in supply chains and bestow a competitive advantage on certified firms. The pursuit of certification may also, on its own, communicate desirable but otherwise unobserved organizational attributes. ${ }^{63}$

While the ISO certification process nominally requires companies to undergo restructuring of their organization and operational processes, a question remains as to whether certification results in actual improvements in firm-level capabilities. Some past studies suggest that achieving ISO certification induces organizations to adopt practices that improve operational performance. ${ }^{64}$ Corbett and Luca (2002) and others have found the process of obtaining ISO certification increases functional compatibility and interoperability according to global norms, thus easing adoption of platform technologies. To be sure, if ISO certification conveys no information at all about quality or capabilities (in expectation), then buyers in the supply chain should tend to ignore it and suppliers should, as a consequence, ultimately cease to seek it. In this sense, we would conjecture that a full decoupling of

62. Breka (1994), Litsikas (1997), and Rao, Ragu, and Solis (1997).

63. Terlaak and King (2006) find that tangible financial incentives justify the outlay of substantial organizational resources to obtain ISO certification The authors examined the effects of ISO 9000 certification on the competitive advantage of US manufacturing firms. Using a panel of firms, they found that firms grew faster after ISO certification, ceteris paribus. Importantly, firms' growth effect was greater in situations where buyers faced greater difficulties in acquiring information about suppliers.

64. Litsikas (1997) and Rao, Ragu, and Solis (1997). 
the certification effect and the quality effect (including revealed quality) is not sustainable in a longer-run equilibrium.

Whether financial benefits clearly accompany certification is another unresolved empirical question. In addition to prior empirical and theoretical work, some evidence is available from survey data. Corbett and Luca (2002) surveyed business executives in fifteen countries in the winter of 2001, receiving just under 3,000 responses. The responses indicated that ISO 9000 certification was considered "important" to the firms' continued success, the most favorable survey choice. ${ }^{65}$ In a study of the impact of ISO quality management standards in Asia, survey data from the United Nations Industrial Development Organization (UNIDO) revealed that 36.1 percent of respondents cited "internal improvement" as their primary reason for choosing to implement a quality-management system (UNIDO 2012). This was the most common reason cited, followed by "customer pressure" (26.1 percent) and "corporate or top management objective" (18.5 percent). With regard to the link to certification and performance, the purchasers surveyed in this report responded that ISO 9000-certified firms performed "better" or "much better" than noncertified suppliers. The World Bank Enterprise Surveys data show a strong positive correlation between ISO certification and exporting activity. ${ }^{66}$ Eighty-eight percent of the time (significant at .01 level), regions with higher proportions of firms with standards certification also recorded greater exporting activity ${ }^{67}$ Further, as shown by Prakash and Potoski (2007), the certification intensity of trading partners has a strong influence on adoption patterns.

Regardless of the direction of the specific causality running between trade and ISO certification, there is ample reason to believe that process standards such as ISO and technical standards such as GSM and TCP/IP (discussed above) have, together, had a dramatic impact on the global economy during its past thirty years of unprecedented growth.

The promise of the next standards to drive change on a global scale lies outside the bounds of reasonable conjecture. But while the nature of standards in the next - and most substantial — phase of the centuries-old process of global economic inclusion is uncertain, the continued centrality of standards is not. A core challenge of global development in the twenty-first century is thus the creation and maintenance of standards that accelerate, rather than impede, innovation at the same time they expand, rather than contract, economic inclusion on a global scale.

65. The authors report that "the average score for ISO 9000 certification across all industries was 3.95 (where 3 corresponds to 'somewhat important' and 4 to 'important')." (Corbett and Luca 2002, 10) The responses for ISO 14000 certification were not as robust and varied between "somewhat important" to "important" for the firms continued success. Demand for ISO 14000 certification typically originated in a firms marketing department rather than a quality control office or from top management, as was the case with ISO 9000.

66. Prakash and Potoski (2007).

67. Authors' pairwise correlation analysis of data from the World Bank Enterprise Surveys, available at http://www.enterprisesurveys.org. 
In the next section we consider a dimension of the advance of the algorithmic frontier of particular significance not only to the past development of the global economy, but also to its future: the impact of the advance of the algorithmic frontier on the discovery of new ideas.

\subsection{Algorithms and the Process of Discovery}

So far in this chapter we have:

- considered the development of the economy of the United States as the frontier has shifted from agricultural, to industrial, to scientific, and finally to algorithmic;

- proposed a theoretical unit of analysis in the study of the algorithmic economy, which we term the "production recipe"; and

- noted the importance of standards in enabling the interoperability of production recipes, with particular attention to how such interoperability has facilitated international trade and accelerated global growth.

What we have not yet done is consider sources of novelty in the algorithmic economy, and how they may be different from those that have driven economic advance in the past. That is the goal of this last section in the chapter.

Following directly from the previous section we certainly can observe that, just as improvements in information and communications technologies associated with the advance of the algorithmic frontier have enabled the decentralization of processes to produce things, so have they led to a decentralization of processes to produce ideas. From the 1940s to the 1980s, when economic advance was bounded by the scientific frontier, a handful of corporate research labs - Bell Telephone Laboratories ("Bell Labs"), RCA Laboratories, the IBM T. J. Watson Research Center, and the Xerox Palo Alto Research Center (PARC), being the leaders - produced an astoundingly disproportionate share of the world's scientific discoveries and technological advances. ${ }^{68}$

The "golden age" of the large-scale corporate research laboratory supported by monopoly rents came to an end in the 1980s, due to a combination of factors including deregulation, the emergence of the conglomerate discount, and changes in the technology of discovery. In its place has emerged a less concentrated system of "divided technical leadership" (Ozcan and Greenstein 2013) involving a global network of smaller-scale corporate laboratories, government laboratories, academic institutions, and start-up ventures. The primary role of large corporations in this system is not to

68. For example, William Shockley and colleagues at Bell Labs developed the silicon transistor, and then went on to understand the underlying science of their innovation, a process that earned them the Nobel Prize in Physics in 1956. For more on Bell Labs, see Gertner (2012); regarding the "golden age" of corporate research labs, see Auerswald and Branscomb (2005). 
generate new innovations themselves, but rather to produce and market such innovations at mass scale. ${ }^{69}$

The decentralization of the production of ideas enabled by the advance of the algorithmic frontier is one dimension of change in the process of discovery. A second - and more fundamental — one relates to methodologies of discovery themselves.

Among biologists the notion that life is fundamentally algorithmic earned a central place in theory decades ago. Most of the great discoveries in biological sciences in the twentieth century - the discovery of the double helix, most notably among them - were inspired by the work of pioneers of information theory notably including Norbert Wiener and Claude Shannon. As Sydney Brenner, the 2002 Nobel Laureate in medicine, said in 1971: "I feel that this new molecular biology has to go in this direction - to explore the high-level logical computers, the programs, the algorithms of development" (Gleick 2011,300). The result of biologists' shift to focusing on "the algorithms of development" has been a revolution in the life sciences that continues to unfold today, with dramatic effects.

Advances in understanding about the nature of biological systems have translated directly into advances in actual technologies of discovery in the life sciences. Techniques such as combinatorial chemistry and highthroughput screening are today encoded in "lab-on-a-chip" technologies, ${ }^{70}$ turning Schumpeter's vision of the search for economically valuable "new combinations" into algorithmically driven pieces of hardware capable of doing the work of dozens, if not hundreds, of postdocs using the methods of two decades ago.

In contrast, the advance of discovery in economics was, from the 1950s to the 1980s, firmly rooted in the logical positivist project of deriving theories from axiomatic foundations, then subjecting them to empirical test using econometric methods. The development and increasing influence within economics of lab experiments, field experiments, and even applications of neuroscience in the 1990s to the present has greatly increased the methodological diversity of the discipline.

Until recently, however, the social sciences (economics in particular) have remained separated from the life sciences and the physical sciences by ordersof-magnitude differences in both the availability and the reliability of data. The relatively poor quality of data available to social scientists and the perceived impracticability of conducting controlled economic experiments at large scale has necessitated the development by economists of methods of causal inference far more elaborate than those employed in other sciences.

69. Auerswald and Branscomb (2005).

70. A pioneer in this work is Caliper Technologies, founded by Larry Bock and Michael Knapp in 1995. 
However-as is well known and widely discussed as the advent of "big data"- data on people's behavior in social contexts is increasing in quantity and improving in quality at an astounding rate. As a consequence, there is ample reason to believe that continued advances in the algorithmic frontier over the next two decades will transform the process of discovery in economics and other social sciences just as they have been doing for the past two decades in the life sciences.

\subsection{Conclusion}

Vannevar Bush is best known as the author of Science: The Endless Frontier, which provides the inspiration for this volume, for his work during World War II as director of the US Office of Scientific Research and Development, and for his part in the development of analogue computers. However, one of Bush's most powerful and enduring contributions may have been that which he made via a July 1945 magazine article in The Atlantic titled, "As We May Think," which was published just weeks before V-J Day. As he looked ahead to the frontier of societal advance in the postwar era, his emphasis was not on the products of publicly funded science but on the capacities of privately produced tools: "The world has arrived at an age of cheap complex devices of great reliability; and something is bound to come of it." In that essay, he envisions how existing low-cost technologies might be further advanced and networked into a system for the storage and retrieval of ideas, which he called the "memex": "Wholly new forms of encyclopedias will appear, ready made with a mesh of associative trails running through them, ready to be dropped into the memex and there amplified." The existence of this tool would allow for a continuation of the forward progress of human inquiry: "[Man] has built a civilization so complex that he needs to mechanize his records more fully if he is to push his experiment to its logical conclusion and not merely become bogged down part way there by overtaxing his limited memory."

Among those who read this essay in The Atlantic magazine was a twentyfive-year-old aerospace engineer named Douglas Engelbart. Engelbart was so taken by the vision set forth in "As We May Think" that he redirected his career to making that vision a reality. In 1968, at the fall Joint Computer Conference (a semiannual meeting of the then-major computing societies held in San Francisco), Engelbart delivered to over a thousand participants a presentation that set forth for the first time the core elements of the user architecture that would define the information revolution in decades to come: the computer mouse, text editing, hypertext, windowing, and video conferencing.

This story of serendipitous inspiration and invention illustrates the fundamental link between the science-based frontier and the algorithmic fron- 
tier, as well as the differences between the two. Although Vannevar Bush conceived and led the most ambitious and large-scale $\mathrm{R} \& \mathrm{D}$ programs ever undertaken at that time (notably including the Manhattan Project), he was able to look ahead to an era where the greatest progress in science-based discovery would be enabled by lowering the cost of storing and sharing ideas horizontally among scientists. Douglas Engelbart further democratized that vision, prototyping an architecture of interaction through standardized interfaces that we have come to know simply as information and communications technology.

This anecdote also suggests that the legacy of Vannevar Bush is arguably not about the importance of science-based research per se, any more than it is about the creation of the National Science Foundation and the decades of discovery it has enabled. Rather, it is about the importance of understanding that, at any point in time, the frontier of social attainment is changing. When Bush led the committee that produced Science: The Endless Frontier in 1945 , the changing frontier consisted of the transition of an economy based on industrial growth through economies of scale to one based on improved goods and services through science-based innovation. Today, as we have sought to describe above, the frontier is changing again.

Just as the advent of science-based innovation motivated an earlier generation of economists to create new theoretical frameworks and analytic techniques to understand the rate and direction of technical change, so the advance of the algorithmic frontier is challenging the current generation of economists to respond in a like manner. The existence of this volume and the work it contains provides some evidence of the will that exists to meet that challenge.

\section{Appendix}

\section{ISO Management Standards (ISO 2012)}

ISO 9001:2008

ISO 9001:2008 gives the requirements for quality-management systems. Certification to the standard is used in global supply chains to provide assurance about suppliers' ability to satisfy quality requirements and to enhance customer satisfaction in supplier-customer relationships.

Up to the end of December 2011, at least 1,111,698 certificates had been issued in 180 countries and economies, two more than in the previous year. The 2011 total represents a decrease of 1 percent $(-6,812)$ over 2010.

The top three countries for the total number of certificates issued were China, Italy, and Japan, while the top three for growth in the number of certificates in 2011 were Italy, China, and Romania. 
ISO 14001:2004

ISO 14001:2004, which gives the requirements for environmental management systems, retains its global relevance for organizations wishing to operate in an environmentally sustainable manner.

Up to the end of December 2011, at least 267,457 ISO 14001:2004 certificates had been issued, a growth of 6 percent $(+15,909)$, in 158 countries, two more than in the previous year.

The top three countries for the total number of certificates were China, Japan, and Italy, while the top three for growth in the number of certificates in 2011 were China, Italy, and France.

ISO/TS 16949:2009

ISO/TS 16949:2009 gives the requirements for the application of ISO 9001:2008 by suppliers in the automotive sector. Up to the end of December 2011, at least 47,512 ISO/TS 16949:2009 certificates, a growth of 8 percent $(+3,566)$, had been issued in eighty-six countries and economies, two more than in the previous year.

The top three countries for the total number of certificates were China, the Republic of Korea, and the United States, while the top three for growth in the number of certificates in 2011 were China, India, and the Republic of Korea.

ISO 13485:2003

ISO 13485:2003 gives quality-management requirements for the medical device sector for regulatory purposes. Up to the end of December 2011, at least 20,034 ISO 13485:2003 certificates, a growth of 6 percent $(+1,200)$, had been issued in ninety-five countries and economies, two more than in the previous year.

The top three countries for the total number of certificates were the United States, Germany, and the United Kingdom, while the top three for growth in the number of certificates in 2011 were the United States, Israel, and Japan.

ISO/IEC 27001:2005

ISO/IEC 27001:2005 gives the requirements for information securitymanagement systems. At the end of December 2011, at least 17,509 ISO/IEC 27001:2005 certificates, a growth of 12 percent $(1,883)$, had been issued in one hundred countries and economies, eight less than in the previous year.

The top three countries for the total number of certificates were Japan, India, and the United Kingdom, while the top three for growth in the number of certificates in 2011 were Japan, Romania, and China.

ISO 22000:2005

ISO 22000:2005 gives the requirements for food-safety management systems. Up to the end of December 2011, at least 19,980 ISO 22000:2005 
certificates, a growth of 8 percent $(1,400)$, had been issued in 140 countries and economies, two more than in the previous year.

The top three countries for the total number of certificates were China, Greece, and Romania, while the top three for growth in the number of certificates in 2011 were China, Italy, and Romania.

ISO 50001:2011

ISO 50001:2011 gives the requirements for energy-management systems. It was published in mid-June 2011. Up to the end of December 2011, at least 461 ISO 50001:2011 certificates had been issued in thirty-two countries and economies. The top three countries for the total number of certificates were Spain, Romania, and Sweden.

\section{References}

Acs, Z. J. 2013. Why Philanthropy Matters: How the Wealthy Give, and What It Means for Our Economic Well-Being. Princeton, NJ: Princeton University Press.

Acs, Z. J., and L. Preston. 1997. "Small and Medium-Sized Enterprises, Technology, and Globalization: Introduction to a Special Issue on Small and Medium-Sized Enterprises in the Global Economy." Small Business Economics 9 (1): $1-6$.

Aghion, P., and P. Howitt. 1992. "A Model of Growth through Creative Destruction." Econometrica 60 (2): 323-51.

Arrow, K. J. 1962. "The Economic Implications of Learning by Doing." Review of Economic Studies 29 (3): 155-73.

1974. The Limits of Organization. New York: Norton.

Arthur, W. B. 2009. The Nature of Technology: What It Is and How It Evolves. New York: Free Press.

Arthur, W. B. 2011. "The Second Economy." McKinsey Quarterly October (4). http:// www.mckinsey.com/insights/strategy/the_second_economy.

Auerswald, P. 2008. "Entrepreneurship in the Theory of the Firm." Small Business Economics 30:111-26.

2010. "Entry and Schumpeterian Profits: How Technological Complexity Affects Industry Evolution." Journal of Evolutionary Economics 20:553-82.

- 2012. The Coming Prosperity: How Entrepreneurs are Transforming the Global Economy. New York: Oxford University Press.

Auerswald, P., and L. M. Branscomb. 2005. "Edwin Mansfield, Technological Complexity, and The 'Golden Age' of US Corporate R\&D.” Journal of Technology Transfer 30 (1/2): 139-57.

2008. "Research and Innovation in a Networked World." Technology in Society 30 (3-4): 339-47.

Auerswald, P., S. Kauffman, J. Lobo, and K. Shell. 2000. "The Production Recipes Approach to Modeling Technological Innovation: An Application to Learning by Doing." Journal of Economic Dynamics and Control 24:389-450.

Baldwin C., and K. Clark. 2000. Design Rules: Volume 1. Cambridge, MA: MIT Press. 
Baldwin, R. E., and P. Martin. 1999. "Two Waves of Globalisation: Superficial Similarities, Fundamental Differences." NBER Working Paper no. 6904, Cambridge, MA. http://www.nber.org/papers/w6904.

Biddle, B., A. White, and S. Woods. 2010. "How Many Standards in a Laptop? (And Other Empirical Questions)." SSRN Scholarly Paper no. ID 1619440, Social Science Research Network. http://papers.ssrn.com/abstract=1619440.

Blind, K. 2004. The Economics of Standards: Theory, Evidence, Policy. Northampton, MA: Edward Elgar Publishing.

Blind, K., and A. Jungmittag. 2008. "The Impact of Patents and Standards on Macroeconomic Growth: A Panel Approach Covering Four Countries and 12 Sectors." Journal of Productivity Analysis 29 (1): 51-60.

Bloom, N., and J. Van Reenen. 2010. "Why Do Management Practices Differ across Firms and Countries?" Occasional Paper no. 26, Centre for Economic Performance. Retrieved July 14, 2013 from http://cep.lse.ac.uk/.

Bordo, M. D., A. M. Taylor, and J. G. Williamson. 2003. "Introduction.” In Globalization in Historical Perspective, edited by M. D. Bordo, A. M. Taylor, and J. G. Williamson, 1-10. Chicago: University of Chicago Press.

Brady, Robert A. 1961. Organization, Automation, and Society: The Scientific Revolution In Industry. Berkeley and Los Angeles: University of California Press.

Breka, J. 1994. "Study Finds Gains with ISO 9000 Registration Increase over Time." Quality Progress May:18-20.

Bresnahan, T. F., and M. Trajtenberg. 1995. "General Purpose Technologies: 'Engines of Growth'?” Journal of Econometrics 65 (1): 83-108.

Bureau of Economic Analysis. 2013. "Summary Estimates for Multinational Companies: Employment, Sales, and Capital Expenditures for 2011.” April 18. http:// www.bea.gov/newsreleases/international/mnc/2013/_pdf/mnc2011.pdf.

Busch, Lawrence. 2011. Standards: Recipes for Reality. Cambridge, MA: MIT Press.

Bush, V. 1945a. "As We May Think.” The Atlantic, July http://www.theatlantic.com/ magazine/archive/1945/07/as-we-may-think/303881/.

. 1945b. Science: The Endless Frontier. Washington, DC: US Government Printing Office.

Chandler, A. D. 1990. Scale and Scope: The Dynamics of Industrial Capitalism. Cambridge, MA: Belknap/Harvard University Press.

_. 1992. "Organizational Capabilities and the Economic History of the Industrial Enterprise." Journal of Economic Perspectives 6 (3): 79-100.

Chen, M. X., J. Wilson, and T. Otsuki. 2008. "Standards and Export Decisions: Firm-Level Evidence from Developing Countries.” Journal of International Trade \& Economic Development 17:501-23.

Clougherty, J. A., and M. Grajek. 2012. "International Standards and International Trade: Empirical Evidence from ISO 9000 Diffusion." NBER Working Paper no. 18132, Cambridge, MA.

Coase, R. H. 1937. "The Nature of the Firm." Economica 4:386-405.

Corbett, C. J., and A. Luca. 2002. "Global Survey on ISO 9000 and ISO 14000: Summary of Findings." Working Paper. http://personal.anderson.ucla.edu/charles .corbett/papers/iso_survey_report_us.pdf.

David, P. A. 1987. "Some New Standards for the Economics of Standardization in the Information Age." In Economic Policy and Technological Performance, edited by P. S. Dasgupta and P. Stoneman, 206-39, Centre for Economic Policy Research. Cambridge: Cambridge University Press.

David, P. A., and S. Greenstein. 1990. "The Economics of Compatibility Standards: An Introduction to Recent Research 1." Economics of Innovation and New Technology 1 (1-2): 3-41. 
Dodd, A. Z. 2012. The Essential Guide to Telecommunications. Upper Saddle River, NJ: Prentice Hall.

Farrell, J., and T. Simcoe. 2013. "Four Paths to Compatibility." In The Oxford Handbook of the Digital Economy, edited by M. Peitz, and J. Waldfogel. New York: Oxford University Press.

Furusten, S. 2002. "The Knowledge Base of Standards." In A World of Standards, edited by N. Brunsson and B. Jacobsson. New York: Oxford University Press.

Gertner, J. 2012. The Idea Factory: Bell Labs and the Great Age of American Innovation. New York: Penguin Books.

Gleick, James. 2011. The Information: A History, a Theory, a Flood. New York: Random House.

Goldfarb, A., and B. Yang. 2009. "Are All Managers Created Equal?” Journal of Marketing Research 46 (5): 612-22.

Gottschalk, R., and S. Griffith-Jones. 2010. "Basel II Implementation in Lowincome Countries: Challenges and Effects on SME Development." In The Basel Capital Accords in Developing Countries: Challenges for Development Finance, edited by Ricardo Gottschalk. Basingstoke, Hampshire, UK: Palgrave Macmillan.

Griliches, Z. 1957. "Hybrid Corn: An Exploration in the Economics of Technological Change." Econometrica 25:501-22.

Guasch, J. L., J.-L. Racine, I. Sanchez, and M. Diop. 2007. Quality Systems and Standards for a Competitive Edge. Washington, DC: World Bank Publications.

Hagel III, J., and J. S. Brown. 2005. The Only Sustainable Edge: Why Business Strategy Depends on Productive Friction and Dynamic Specialization. Boston: Harvard Business School Press.

Hausmann, R., C. A. Hidalgo, S. Bustos, M. Coscia, S. Chung, J. Jimenez, A. Simoes, and M. A. Yildirim. 2011. The Atlas of Economic Complexity: Mapping Paths to Prosperity. Cambridge, MA: MIT University Press. http://atlas.media.mit.edu/book/.

Hidalgo, Céssar A., and Ricardo Hausmann. 2009. "The Building Blocks of Economic complexity," Proceedings of the National Academy of Sciences, 106: 10570-75.

International Organization for Standardization. 2004. "Standardization and Related Activities: General Vocabulary.” http://www.iso.org/iso/iso_iec_guide_2_2004.pdf.

. 2012. "The ISO Survey of Management System Standard Certifications, 2011." http://www.iso.org/iso/iso-survey.

International Organization for Standardization and International Electrotechnical Commission (2014). "About Standardization and Conformity Assessment." http:// www.standardsinfo.net/info/aboutstd.html.

Jewkes, J., D. Sawers, and R. Stillerman. 1958. The Sources of Invention. London: McMillan \& Co.

Jorgenson, D. W., and K. J. Stiroh. 2000. "Raising the Speed Limit: US Economic Growth in the Information Age." Brookings Papers on Economic Activity 31 (1): $125-236$.

Kalba, K. 2008. "The Adoption of Mobile Phones in Emerging Markets: Global Diffusion and the Rural Challenge." International Journal of Communication 2:631-61.

Kindleberger, C. P. 1983. "Standards as Public, Collective and Private Goods." Kyklos 36 (3): 377.

Knuth, D. 1972. "Ancient Babylonian Algorithms." Communications of the ACM 15 (7): 671-77.

Kremer, M. 1993. "Population Growth and Technological Change: One Million B.C. to 1990." Quarterly Journal of Economics 108 (3): 681-716. doi:10.2307/2118405.

Landes, D. 1983. Revolution in Time Clocks and the Making of the Modern World. Cambridge, MA: Belknap Press. 
Lee, J., and A. G. Schmidt. 2010. "Research and Development Satellite Account Update, Estimates for 1959-2007." Survey of Current Business December:16-56.

Levinson, M. 2008. The Box: How the Shipping Container Made the World Smaller and the World Economy Bigger. Princeton, NJ: Princeton University Press.

Litsikas, M. 1997. "Companies Choose ISO Certification for Internal Benefits." Quality 36:20-26.

Mansfield, E. 1961. "Technical Change and the Rate of Imitation." Econometrica 29: 741-66.

- "The Speed of Response of Firms to New Techniques." Quarterly Journal of Economics 77 (2): 290-311.

Murphy, C., and J. Yates. 2009. The International Organization for Standardization (ISO): Global Governance through Voluntary Consensus. London: Routledge.

Nelson, R. R., and S. G. Winter. 1982. An Evolutionary Theory of Economic Change. Cambridge, MA: Harvard University Press.

NIST/SEMATECH. 2012. "e-Handbook of Statistical Methods." Accessed August 24, 2012. http://www.itl.nist.gov/div898/handbook/index.htm.

Ozcan, Y., and S. Greenstein. 2013. "The (de)Concentration of Sources of Inventive Ideas: Evidence from ICT Equipment." Unpublished manuscript.

Palmisano, S. J. 2006. "The Globally Integrated Enterprise.” Foreign Affairs May/ June. http://www.foreignaffairs.com/articles/61713/samuel-j-palmisano/the-globally -integrated-enterprise.

Prakash, A., and M. Potoski. 2007. "Investing Up: FDI and the Cross-Country Diffusion of ISO 14001 Management systems1.” International Studies Quarterly 51:723-44.

Raballand, G., and E. Aldaz-Carroll. 2007. "How Do Differing Standards Increase Trade Costs? The Case of Pallets." World Economy 30:685-702.

Rao, S., T. S. Ragu, and L. E. Solis. 1997. "Does ISO 9000 Have an Effect on Quality Management Practices? An International Empirical Study.” Total Quality Management 8:335-46.

Rivkin J. 2000. "Imitation of Complex Strategies.” Management Science 46:824-44.

Romer, P. M. 1986. "Increasing Returns and Long-Run Growth." Journal of Political Economy 94:1002-37.

- 1990. "Endogenous Technological Change." Journal of Political Economy 98 (5): S71-102.

- 1996. "Why, Indeed, in America? Theory, History, and the Origins of Modern Economic Growth." American Economic Review 86 (2): 202-06.

Rycroft, R. W., and D. E. Kash. 1999. The Complexity Challenge: Technological Innovation for the 21st Century. New York: Thomson Learning.

Sauter, R., and J. Watson. 2008. Technology Leapfrogging: A Review of the Evidence. Report for UK Department of International Development, SPRU, University of Sussex. http://sro.sussex.ac.uk/29299/.

Schumpeter, Joseph A. 1912. Theorie der witschaftlichen Entwicklung. Leipzig: Duncker \& Humblot. Translated by Redvers Opie as The theory of economic development. (Oxford: Oxford University Press, 1934). Cited edition is New Brunswick, NJ: Transaction Publishers, 1982.

1928. "The Instability of Capitalism." Economic Journal 38:361-86.

Sen, A. 2002. "How to Judge Globalism." American Prospect 13 (1): $2-7$.

Shepherd, W. R. 1923. Historical Atlas. New York: Henry Holt.

Simcoe, T. S. Forthcoming. "Modularity and the Evolution of the Internet." In Economics of Digitization, edited by A. Goldfarb, S. Greenstein, and C. Tucker. Chicago: University of Chicago Press.

Simon, H. A. 1967. "Programs as Factors of Production." California Management Review 10 (2): 15-22. 
Swann, G. M. P. 2009. "International Standards and Trade: A Review of the Empirical Literature." Paper presented at the conference on Barriers to Trade: Promoting Good Practice in Support of Open Markets. http://www.oecd.org/trade/ non-tariffmeasures/43685142.pdf.

Terlaak, A., and A. A. King. 2006. "The Effect of Certification with the ISO 9000 Quality Management Standard: A Signaling Approach.” Journal of Economic Behavior and Organization 60:579-602.

Trajtenberg, M., R. Henderson, and A. Jaffe. 1992. "Ivory Tower versus Corporate Lab: An Empirical Study of Basic Research and Appropriability.” NBER Working Paper no. 4146, Cambridge, MA. http://www.nber.org/papers/w4146.

Turner, F. J. 1894. "The Significance of the Frontier in American History." State Historical Society of Wisconsin.

United Nations Industrial Development Organization (UNIDO). 2012. "Study into the Value of ISO 9001." Accessed September 25, 2012. http://www.iaf.nu/articles/ Study_into_the_value_of_ISO_9001_/279.

Vanderbilt, T. 2012. "The Single Most Important Object in the Global Economy." Slate, August 14. http://www.slate.com/articles/business/transport/2012/08/pallets _the_single_most_important_object_in_the_global_economy_.2.html.

Weitzman, M. L. 1998. "Recombinant Growth." Quarterly Journal of Economics 113 (2): 331-60.

Winter, S. G. 1968. Toward a Neo-Schumpeterian Theory of the Firm. Santa Monica, CA: Rand Corporation.

World Trade Organization. 2005. World Trade Report 2005: Trade Standards and the WTO. Geneva, Switzerland. http://www.wto.org/english/res_e/publications_e/ wtr05_e.htm.

2008. World Trade Report 2008: Trade in a Globalizing World. Geneva, Switzerland. http://www.wto.org/english/res_e/reser_e/wtr08_e.htm.

\section{Comment Timothy Simcoe}

This chapter by Agwara, Auerswald, and Higginbotham (AAH) is an ambitious and thought-provoking attempt to describe how innovation at the "algorithmic frontier" links process innovation to globalization and economic growth. They begin with a historical discussion that emphasizes how ideas about the nature of the frontier have changed over time, gradually shifting from geographic expansion, to industrialization, to the scientific frontier described by Vannevar Bush and commemorated in this volume. The chapter's main thesis is that the scientific frontier has been replaced by an "algorithmic" frontier characterized by IT-enabled business process innovation and increasingly fragmented global supply chains. After describing this new frontier, the authors consider its implications for science and innovation policy.

Timothy Simcoe is associate professor of strategy and innovation at Boston University and a faculty research fellow of the National Bureau of Economic Research.

For acknowledgments, sources of research support, and disclosure of the author's or authors' material financial relationships, if any, please see http://www.nber.org/chapters/c13031.ack. 